\title{
The American Commercial Religion
}

\author{
Haider Ala Hamoudi*
}

\section{INTRODUCTION}

While there is no shortage of work that might describe the Federal Constitution as a form of sacred text, ${ }^{1}$ or constitutionalism generally as being driven by faith more than rational adherence, ${ }^{2}$ the notion of a commercial law faith driven by a sacred text is comparatively unexplored. The generally undiscussed assumption seems to be that commerce, being about money, is inherently grounded in rational concerns, divorced from the type of reverence one affords to a sacred text and stripped of the type of largely unquestioning obeisance that attaches at least to more conservative manifestations of religious faith. Yet the assumption, this Article shall show, is in many fundamental ways quite wrong.

Far from being any sort of ordinary law organizing commerce, the Uniform Commercial Code in fact is our godhead, our sacred foundational document, our Holy Book of modern commerce, which brought us a form of economic enlightenment from the pre-Code Days of Ignorance. ${ }^{3}$ We often refer to it as the "Code," for no more description is necessary, any more than a believer need elaborate on the text referred to as the "Book" when discussing Sacred Text among fellow believers. While the Code has been subject to revisions in the manner that a Sacred Text is generally not, it should be noted that revisions by the disciples of the appointed prophets who served as original drafters have become increasingly difficult, as would be expected of any Holy

* Assistant Professor of Law, University of Pittsburgh School of Law. I would like to thank Ron Brand, Vivian Curran, Harry Flechtner, George Taylor, and the members of the University of Pittsburgh junior faculty forum (specifically Jessie Allen, Mirit Eyal-Cohen, Jessie Allen, Charles Jalloh, Jan Osei-Tutu, Michelle Slack) for their generous comments and support. Any and all errors are my own.

1. See George P. Fletcher, Three Nearly Sacred Books in Western Law, 54 Ark. L. Rev. 1, 2-11 (2001).

2. One of the most influential such accounts is, of course, the magnificent work of Sanford Levinson on the subject. See generally Sanford Levinson, Constitutional Faith (1988).

3. The reference is Muslim, in Arabic jahiliyya, and refers to the practices of Arabia prior to the appearance of Muhammad and the delivery of the Qur'an to him though the archangel Gabriel. Noah Feldman, After Jihad: America and the Struggle for Islamic DemocRACY 43 (2003). 
Book as its life lengthens and attachment to it deepens. ${ }^{4}$ The revision process, we are told, is increasingly "heated" and "partisan," 5 something by implication, and with the sweetest irony, we seem to believe had not been the case when Realist prophets named Llwellyn and Gilmore put pen to paper. ${ }^{6}$ Given these trends, the Code may in the future become all but unamendable.

Not necessarily comfortable equating our faith in the Code with religious faith, which is not often defended on the basis of reason, we commercial lawyers are quick to defend our beliefs as inherently rational by touting the Code's benefits. Put differently, the reasons for our adherence, we insist, simply relate to the fact that the Code works to maximize commercial and economic benefit. This is not some sort of religious adoration of the sacred, we tell ourselves, but rather the rational pursuit of material gain.

In keeping with these ideas, we describe the Code's language as clear and definite. ${ }^{7}$ However, the commitment of the believer to text on bases other than rational may be involved here, for our courts at least at times commit themselves to the $u_{r t e x t}{ }^{8}$ as if it were somehow clear and definite even as to provisions that we, indeed even as the prophet-drafters themselves, acknowledge to be anything but clear. ${ }^{9}$

4. See infra Part II(B)(3).

5. Douglas G. Baird et al., Commercial and Debtor-Creditor law: Selected StatUTES 1 (Thomson Reuters/Foundation Press 2010).

6. The irony, of course, stems from the fact that it was the Realists themselves who suggested that both the creation and interpretation of law can not realistically be insulated from external influences, including the political. Oliver Wendell Holmes, Jr., The Common Law 1 (1881). As Holmes stated,

The life of the law has not been logic; it has been experience. The felt necessities of the time, the prevalent moral and political theories, intuitions of public policy, avowed or unconscious, even the prejudices which judges share with their fellow-men, have had a good deal more to do than the syllogism in determining the rules by which men should be governed.

Id. See also American Legal Realism 3-4 (William W. Fisher III, Morton J. Horowitz, \& Thomas A. Reed, eds. 1993) (describing the preceding Holmes passage as being "inspirational" to most Realists).

7. Arthur Linton Corbin, The Uniform Commercial Code-Sales; Should It Be Enacted?, 59 YALE L.J. 821, 824 (1950); Taylor v. Roeder, 360 S.E.2d 191, 195 (Va. 1987) ("The U.C.C. introduced a degree of clarity into the law of commercial transactions which permits it to be applied by laymen daily to countless transactions without resort to judicial interpretation."). The UCC defines one of its premier aims as being to "clarify" the law. U.C.C. § 1-103(a)(1) (2011).

8. The urtext refers to an original unadulterated (and most authentic) text, prior to changes or editions having been made thereto. Collins English Dictionary: Complete and UnABRIDGED (5th ed. 2003). In the context of the UCC, this would mean the text produced by the drafting institutions, free of the adulterations of the various state legislatures.

9. See infra Part IV(B) (indicating that an example of near spiritual adherence to the language of section 2-207 in the absence of any rational defense for it is provided in the case of Filanto, S.p.A. v. Chilewich Int'l Corp., 789 F. Supp. 1229 (S.D.N.Y. 1992)). As any first year Contracts 
The Code, we also say, is modern and practical. It dispenses with cumbersome common law artifacts (such as, to use only examples as they arise in Article 2 of the U.C.C., the pre-existing duty rule, ${ }^{10}$ requirements of mutuality, ${ }^{11}$ and attributions of title ${ }^{12}$ ) and imposes in their place rules that appear to reflect well the manner in which commercial actors deal with one another.

And so it may well be, for the most part, simple and clear, practical and modern. However, its greatest benefit, at least from an economic and commercial perspective, is not as much the reason for our faith in it, but rather the product thereof. It is, as its name indicates, uniform. Simplicity and clarity, practicality and modernity, serve little purpose if there existed fifty disparate versions of it throughout the United States. This is not so with the Code. ${ }^{13}$ In marked contrast to the results of other uniform law processes sponsored jointly by the American Law Institute (ALI) and the National Conference of Commissioners on Uniform State Laws (also known as the Uniform Law Commission, or ULC), ${ }^{14}$ where efforts to achieve uniformity have reached results that vary from mild success to as abysmal a fail-

student knows, section 2-207 is perhaps among the worst examples of turgid and opaque language in the entire Code, so awful that even Grant Gilmore, a principal draftsman of the U.C.C., described it as a "miserable, bungled, patched-up job." Letter from Grant Gilmore, Professor, Vt. Law Sch., to Robert S. Summers, Professor, Cornell Univ. Law Sch. (Sept. 10, 1980), as reprinted in James J. White, Contracting Under Amended 2-207, 2004 Wis. L. Rev. 723, 724 (2004) [hereinafter Gilmore Letter].

10. See Wis. Knife Works v. Nat'l Metal Crafters, 781 F.2d 1280, 1285-86 (7th Cir. 1986) (citing U.C.C. \$ 2-209 (2011)) (indicating that the pre-existing duty rule is the historic common law rule that one must supply additional consideration in order for a modification to a contract to be effective, a requirement dispensed with by section 2-209 of the U.C.C.).

11. William L. Prosser, Open Price in Contracts for the Sale of Goods, 16 MinN. L. REv. 733, 734-36 (1932) (indicating that the requirement of mutuality often prevented enforcement of contracts such as those containing open price terms). Prosser stated,

It has been a settled rule, since the early civil law, that the price must be fixed with reasonable certainty. But this rule is subject to the qualification, which has caused endless confusion in contracts decisions, that in certain ill-defined situations the court will remove all certainty by supplying an implication that the parties agree to do what is reasonable.

Id. (citations omitted). See U.C.C. $§ 2-305 \mathrm{cmt} .1$ (1962) (indicating that this has been replaced by U.C.C. section 2-305 which permits such contracts, and that the previous doctrine restricting enforcement of open price term contracts was being rejected).

12. Corbin, supra note 7, 825-27 (indicating that the common law used the term "title" to provide some form of illusion of certainty as to ownership of goods, where the Code focuses on operative facts and legal results pertaining to ownership rather than ascribing some value to the fact that someone possesses some metaphysical attribution of "title").

13. Marion W. Benfield, Jr. \& Michael M. Greenfield, Sales 5 (5th ed. 2006).

14. See discussion infra Part II (describing the role of these sponsoring organizations in the uniform law processes). 
ure as could possibly be imagined, ${ }^{15}$ the strict and near-total universal uniformity of the Code as enacted across all of the states, the District of Columbia, and the U.S. Virgin Islands is nothing short of breathtaking.

Yet this might well prove too much. It might demonstrate that something beyond the rational is at work. That is, perhaps the greatest evidence for the totemic value of the words of the Code's urtext is at times irrational rigor of the uniformity that is demanded. These are fifty separate state sovereigns, after all, under widely varying political, economic and social circumstances. One might expect a state behaving rationally so as to maximize its own benefit (or even a set of politicians within a state acting purely in self interest so as to satisfy local influences) and to adhere to uniformity as a general matter inasmuch as commercial matters are concerned. However, one would surely also expect such a state to dispense with uniformity when it did not seem to lead to efficient results, or when interest groups that might be strong in that state demanded a different result. This might be a fair characterization of the manner in which other uniform laws are approached on a state-by-state basis given the less than rigorous adherence afforded them. ${ }^{16}$

Our attachment to the Code, however, runs far deeper and resembles more that of the religious believer, who would never hear of such nonuniformity in matters of faith. Religion comes in many forms, of course, and adherence to them, particularly in this vast, diverse country of ours, is by no means uniform. Nevertheless, focusing on its more conservative and traditionalist manifestations, "fundamentalist" religion let us (reductively) call it for now for lack of a better term, inspires a certain rigor in its rules and application that plainly exceed those that might be defended in all contexts on the basis of utility or reason. They are grounded instead in the notion of obedience to Divine Command. One may not persuade a deeply committed Jew that the requirement for not working on shabbat might be moved from Saturday to Sunday on one week for reasons relating to weather, nor

15. See Legislation, Uniform L. Commission, http://www.nccusl.org/Legislation.aspx (last visited Nov. 21, 2011) (indicating the uniform laws and their state by state legislative enactments). See also infra Part II(A) (discussing specific examples of moderate failures and successes).

16. Cf. Larry E. Ribstein \& Bruce H. Kobayashi, An Economic Analysis of Uniform State Laws, 25 J. Legal Stud. 131, 132 (1996) (featuring a law and economics approach to the uniform laws processes and arguing that states generally adopt those uniform law proposals that are most efficient, but that there are times when the ULC does manage to influence adoption of less efficient uniform laws, particularly with part time legislatures whose own capacities at lawmaking are necessarily diminished and who might therefore be more amenable to using the products promulgated by the ULC). 
could one persuade a committed Muslim the same respecting the Friday prayers. It is not a question of doing that which might seem on its surface more reasonable, it is submission to the Will of an Almighty who has commanded otherwise.

Something similar is at work as concerns our commitments to the Code, and to the maintaining of strict uniformity thereof. We view the tampering of the Word with grave concern. Far from considering minor state-by-state nonuniform deviations from the Code's text to be reasonable, efficient or salutary applications of Justice Brandeis' stateas-laboratory metaphor, ${ }^{17}$ the deviations are a form of disobedience, almost an apostasy. They are akin to declaring that while the only deity that exists is God, there is an Apostle after Muhammad. ${ }^{18}$ Under such circumstances, and understanding the nature of its transgression as having been of a religious nature, a state may well retreat, recanting its heresy to the Church Galileo-like and returning to the fold. ${ }^{19}$ Or it may persist in its blasphemy, thereby prompting urgent calls for the high priests to find a way to heal the schism. ${ }^{20}$ But when the matter is so framed, it is fair to describe deviations as rare and forced to the margins. It would almost surely not be so in the absence of this commercial religion.

While there is no shortage of discussion on faith in matters of constitutional law in particular, ${ }^{21}$ similar faith-like conduct in the area of commercial law and regulation $^{22}$ is difficult to identify elsewhere. We

17. New State Ice Co. v. Liebmann, 285 U.S. 262, 311 (1932) (Brandeis, J., dissenting).

18. The reference here is to the Muslim profession of faith, in which it is declared that there is no deity but God, and Muhammad is God's Messenger. Revisions to this that suggest that Muhammad may well be Messenger, but that there is another following him have been received among Islamist groups with strong hostility. See Rudolph Peters, Crime and Punishment in Islamic Law: Theory and Practice from the Sixteenth to the Twenty-first Century 158 (2005) (describing the persecution of the Ahmadiyya sect in Pakistan).

19. See infra Part II(B)(1).

20. See infra Part II(B)(1).

21. See infra Part II(C).

22. There are, of course, familiar criticisms of "free market fundamentalism" offered by George Soros, Joseph Stiglitz and others respecting a belief in the sanctity of free markets as functioning effectively in all instances and requiring an absolute minimum by way of legal regulation. Nick Beams, Soros Warns of "Market Fundamentalism," World Socialist Web site (Dec. 22, 1998), http://www.wsws.org/articles/1998/dec1998/soro-d22.shtml; Brian Snowdon, Redefining the Role of the State: Joseph Stiglitz on Building a 'Post-Washington Consensus', 2 World ECON. 45, 48 (2001) (describing Stiglitz's skepticism), available at http://www2.gsb. columbia.edu/faculty/jstiglitz/download/2001_World_Economics.pdf. See also Robert H. NeLson, Economics as a Religion: from Samuelson to Chicago and Beyond (2001). While I freely admit having been inspired to describe Code obedience as "fundamentalist" on the basis of such work, the model of "market fundamentalism" is different from that described herein. Here we speak of religious-like adherence to a particular model of legal regulation, one that betrays some level of affinity to "free market fundamentalism" to be sure, but also transcends it in its demand for obedience to one single text as Word. American preferences for rules respect- 
are not accustomed in our times to thinking of matters of commerce being driven by religious adherence. Nevertheless, Islamic finance offers a convenient analogy. There, likewise on the basis of Sacred Text and derivations of medieval provenance, an entire practice has been woven, and broad convergence achieved, all on the basis of adherence to God's Law, with deviations no less tolerated, and recanting no more likely, than with the Code. ${ }^{23}$

And, yet, as concerns uniformity and the Code, is this a problem? After all, uniformity brings state-by-state convergence on commercial text that is clear and simple, modern and practical. If state-by-state convergence is by and large (even if demonstrably not in every single instance) a good thing, then should it matter whether or not this convergence has been achieved on the basis of rational calculation of economic good or as some form of obedience to sacralized Holy Text? May we not judge the matter solely by its outcome and not concern ourselves with the balance? If we do, can there be any doubt that what has been achieved by any rational measure has been wildly successful even if the adherence demonstrates something else to have been at work to achieve it?

This brings us to the nub. Let us assume for now that our religious faith in our Code has been over the past several decades salutary, and there are good and plenty reasons to believe that, and that the uniformity that is its product has on balance permitted massive economic progress, a nugget of conventional wisdom I choose not to question. Still, now that the Code has achieved all of this for America, it might be time to face more a central drawback in this rapidly globalizing world, of which America is only a part, and a necessarily diminishing one (by which I do not presage America's decline, but only mean to suggest that its portion of the world's economic output will necessarily decrease as the developing world advances). The problem is not that we have been economically harmed by our faith in our Code but rather, to get to the thesis of this paper, that a near fundamentalist obedience to our Code as religious dogma has hindered the very type of global uniformity, and the attendant benefits thereto, that it continues to enable in the domestic context.

ing burden of proof in matters of warranty, for example, have nothing to do with preferences for a free market over legal regulation; it is hard to imagine why a "free market fundamentalist" would prefer to place the burden on the buyer or the seller. See discussion infra Part IV(A). Rather, what is being demonstrated is an American commercial adherence to its own Code, held in near sacred reverence, over any other form of potential regulation.

23. See infra Part (II)(C). 
So even if our obedience to our Code could be described as rationally and economically beneficial domestically, our inability to reach any form of convergence globally must be described as something of the opposite. Stated differently, to the extent that it is true in the domestic context that uniformity brings prosperity, it would be many times truer in the global one. Convergence (if not entire uniformity, fairly dismissed as a hopeless endeavor given broadly disparate norms and values as concerns matters of commerce) would inure to the benefit of all, and yet to describe such an ambition as far from realized is to understate the matter considerably. Therefore, those who defend the Code on the basis of economic prosperity are in something of a quandary. Something, after all, is both causing domestic uniformity, and inhibiting global convergence. Surely it has nothing to do with some sort of interest in maximizing commercial and economic benefit, for if uniformity maximizes economic benefit and facilitates trade, it would do so as much across national borders as it would across state borders. Rather, what is at work is the belief, the fundamentalist religious belief, if I might describe it so, in adherence to the Code as a form of quasi religious obedience that has inspired the success of the one, and contributed to the failure of the other.

To demonstrate this, I will focus on two areas of attempted global convergence. These correspond to two of the more hallowed Articles of the Code; namely, Article 2, which deals with the sale of goods, ${ }^{24}$ and Article 9, which deals with means to obtain security over debt. ${ }^{25}$ Admittedly, the particularities over the failure of global convergence differ in the two contexts. Article 9 lies in that area of commercial law where all would agree that difficulty exists globally. There is nothing approaching agreement on a means by which debt may be secured on an international scale. ${ }^{26}$ Broad transnational resistance has stymied efforts to reach a comprehensive agreement based on the American model. ${ }^{27}$ Meanwhile, in 2008, five justifiably well-regarded commercial law professors participated on a panel during a "Conference on Globalizing Secured Transaction Law." The panel was entitled, without apparent irony, "Why Isn't Everyone Adopting Revised Article 9, UCC? Should They?" 28 Given the title of the conference, and the

\footnotetext{
24. U.C.C. art. 2 (1962).

25. U.C.C. art. 9 (2001).

26. Mark J. Sundahl, The "Cape Town Approach": A New Method of Making International Law, 44 Colum. J. Transnat'l L. 339, 346-47 (2006).

27. See infra Part (II)(D).

28. Program - Conference on Globalizing Secured Transactions Law, Mar. 13-14, 2008, Thomas JefFerson Sch. of Law, http://students.tjsl.edu/files/academics/TJSL_Program_13-14_ Mar08_rev8.pdf (last visited Oct. 28, 2011).
} 
fact that all fifty states had adopted Revised Article 9 by early 2002,29 the reference was obviously to foreign states simply accepting American text as superior to their own and therefore adopting it as such. It is quite reminiscent of the suggestions of prominent and important proponents of Islamic finance that somehow, had the world only adhered to Islam's commercial principles (perhaps by converting to Islam?), the recent global financial crisis could have been averted. ${ }^{30}$ Neither should be a surprise, it is the nature of the true believer to seek conversion, not compromise. ${ }^{31}$ Still, had the Islamic Law Section of the American Association of Law Schools titled its annual conference "Why Isn't Everyone Adopting Shari'a Law? Should They?" I surmise more eyebrows might have been raised.

The difficulties as they concern the sale of goods are in fact almost as serious, though not as immediately apparent. A large number of nations have adopted the Convention on the International Sale of Goods (CISG), which is intended to harmonize cross border sales of goods. ${ }^{32}$ However, the track record of all too many United States courts interpreting it is anything but encouraging. ${ }^{33}$ The type of disregard and contempt many United States courts seem to have for the CISG, reverting in many cases back to the Code, reminds one of the

29. See William D. Warren \& Steven D. Walt, Secured Transactions in Personal PRoperty (8th ed. 2010).

30. See, e.g., P.K. Abdul Ghafour, Islamic Finance Panacea for Global Crisis: Chapra, ArAB News (Oct. 23, 2008), http://archive. arabnews.com/?page $=6 \&$ section $=0 \&$ article $=115730 \& d=23 \&$ $\mathrm{m}=10 \& \mathrm{y}=2008$ (interviewing well-known Islamic finance proponent Umer Chapra on the benefits of an Islamic financial system).

31. I do not mean by this to make the simplistic and empirically falsifiable claim that it is impossible for a believer to simultaneously adhere to religious doctrine and genuinely commit herself to a political conception of justice that does not enforce it but rather treats other religions with equal respect. I am perfectly happy to concede, indeed to forcefully argue, that the overwhelming majority of committed believers, at least in the United States, and certainly the ones I know within the Muslim community, find political allegiance to the liberal state and religious adherence to religious law doctrine to be uncontroversial in precisely the manner that Rawls anticipates. See John Rawls, Political Liberalism 169 (1993). Yet it is one thing to speak of religious communities tolerating inconsistent religious practices of others and cooperating with others on matters of public concern (police forces, fire departments, school boards, and the like), and quite another to ask a committed believer to compromise over the core tenets of her faith. Applied to the question of commercial law, I would not suggest that American faith in Article 9 prevents cooperation, of the political or economic sort, with states that do not adhere to its principles. I $d o$ maintain that it prevents the creation of a comprehensive system of commercial regulation that might be applied globally because it leaves the believer in Article 9 either agreeing to compromise over central rules contained in Article 9, or seeking to convert the globe to Article 9. When left with such a choice, the believer will always prefer conversion, not compromise.

32. Albert H. Kritzer, CISG: Table of Contracting States, PACE L. SCh. InSt. InT'L Com. L., http://www.cisg.law.pace.edu/cisg/countries/cntries.html (last updated Aug. 3, 2011).

33. See infra Part (IV)(A). 
means by which courts in developing nations refuse to abide by treaty obligations regarding enforcement of arbitral awards, for example, because of their broad hostility to arbitral practice. ${ }^{34}$

The recalcitrance is remarkable, far greater than might be expected even granting some allowance to domestic expressions of parochialism in understanding international treaties. Religion, again, offers the most convenient explanation. Rabbis asked to apply shari'a (or imams asked to apply halakha), are similarly likely to fall back upon their own religious tradition in relatively short order. The alternative forms of rules that would otherwise be applied are not only odd, they are not only difficult to harmonize with the respective clergy member's own normative or ideological commitments, and they not only require interpretive tools with which the relevant interpretive authority might be unfamiliar, but they are also, at some level, false, in that they derive from a religious tradition the clergy member does not believe in. This type of near overt hostility, not merely unfamiliarity but near contempt, is a fair description of the manner in which the U.S. Circuit Courts have approached the CISG. These courts do not so much make a mess of it (perhaps a result to be expected whenever a tribunal applies foreign law) as they openly and contemptuously refuse to apply it, and simply use the U.C.C. rules in their place.

Thus, in both the cases of sales in goods and secured transactions, this paper will demonstrate, there has been a considerable failure to reach convergence and this failure may be attributed (at least in part, at least insofar as blame may be attributed to the United States) on the quasi religious faith the American commercial community continues to ascribe to the Code, and the failure of the faithful to imagine alternative paradigms on which global convergence might be more realistically achieved. In short, what we expect, indeed what we demand, from the world is adoption of the American faith, and as everyone knows by now, universal conversion is hardly a basis upon which to build common ground.

Part II of this paper describes the manner in which we commercial lawyers adhere to the Code as if it were a Sacred Text, and the corresponding commercial legal regulatory system as if it were a form of quasi religious doctrine, offering in the process an analogy to Islamic finance. Part III explains the repercussions as they pertain to global failure to reach any sort of convergence over the obtaining of security for a loan, a major source of concern for commercial actors globally.

34. See, e.g., Chibli Mallat, Commercial Law in the Middle East: From Classical Transactions and Modern Business, 48 Ам. J. CомP. L. 81, 136-38 (2000). 
Part IV shows how, far from being a success, in fact the Convention for the International Sale of Goods is plagued in the American domestic context with a broad refusal of the American judiciary to interpret it according to its own terms in a manner that harmonizes with global expectations. Instead, it falls back upon the Sacred Text, the Code, wherever possible, at times under circumstances where to do so is to ignore clear CISG directive. This demonstrates a failure only slightly less serious than that described over the matter of security over debt. Part V concludes with consideration of broader, future repercussions of these processes.

\section{In the BeginNing WAS THE Word}

\section{A. The Uniform Law Processes and the Code}

It might be tempting to describe uniformity to the Code not as indicative of adherence to Code as Sacred Text, but rather the rational decisions of fifty independent jurisdictions ${ }^{35}$ to understand the value of uniformity in a text they have rationally concluded is the best that can be done. Therefore, the states adhere therefore to the recommendations of the drafters without revision. This piecemeal and almost haphazard approach might describe the results of the uniform law processes more generally, beyond the Code, rather than the Code itself. That is to say, state behavior in those contexts, precisely because it is rational, trends towards some uniformity in some contexts, but is far less coordinated.

The uniform laws project is jointly sponsored by the ALI and the ULC. ${ }^{36}$ According to the ULC's own statistics, nearly one hundred and fifty uniform laws ${ }^{37}$ have been proposed. Compiling a complete and timely set of enactment levels for the many uniform laws from the data provided by the ULC would be time consuming and largely beyond the purposes of this Article. However, to provide a general sense, Professors Ribstein and Kobayashi report, based on a comprehensive review, that as of 1996 (when the number of proposals stood at 103) that fully sixty-two of them had less than twenty state adop-

35. While the UCC has been broadly adopted in all fifty states, Louisiana has not adopted Articles 2 or 2A, finding them incompatible with its own civilian inspired system. BENFIELD \& GREENFIELD, supra note 13, at 5 .

36. Edward J. Janger, Predicting when the Uniform Law Process will Fail: Article 9, Capture and the Race to the Bottom, 83 Iowa L. REv. 569, 576 (1998).

37. Acts, Uniform L. Commission, www.nccusl.org/Acts.aspx (last visited Oct. 28, 2011). In fact, the number is greater than 150 , depending on how one chooses to count the Code, as a separate uniform law for each Article, as the website does, or as a single comprehensive uniform commercial law. 
tions and thirty-seven had less than ten, hardly a stellar record. ${ }^{38} \mathrm{~A}$ more recent commentator, less focused on this particular task, has suggested in passing that half of the uniform law proposals have been adopted by fewer than ten jurisdictions. ${ }^{39}$

Whatever the number, success plainly is rarely complete in the form of universal adoption and varies from proposal to proposal. Moreover, in many cases, the results of the uniform law process are not success at all but rather abysmal failure. To provide an example of moderate success, nineteen states and the U.S. Virgin Islands have adopted the Uniform Probate Code (UPC), according to the ULC. 40 At the other end of the spectrum, the Uniform Computer and Information Technology Act (UCITA) ${ }^{41}$ has been far less successful, receiving a worse reception in fact than if it had been entirely ignored by every single jurisdiction. The ULC reports two states having enacted it. ${ }^{42}$ What the ULC does not mention is that four jurisdictions have passed what are known as "bomb shelter" provisions that are meant to shield UCITA from software users within the state by voiding choice of law provisions that would make UCITA applicable. ${ }^{43}$ In other words, not only have the vast majority of states declined to adopt UCITA, but the number of states that have sought to actively limit its scope to the fullest extent possible is double the number that have adopted it. A worse result for the uniform processes could hardly be imagined.

Thus, it can be said at the very least that a decision by a state not to enact a piece of uniform legislation proposed through the uniform laws process is common. This is in marked contrast to the Code, suggesting that there is something qualitatively different about the Code, something that transcends the general uniform law processes as discussed by other scholars, which deserves attention. ${ }^{44}$ The states do

38. Ribstein \& Kobayashi, supra note 16, at 134-35.

39. Karen J. Sneddon, Beyond the Personal Representative: The Potential of Succession Without Administration, 50 S. TEx. L. REv. 449, 471 (2009) (dealing specifically with issues of probate and the Uniform Probate Code and as such is less concerned with the uniform laws process generally).

40. See Acts: Probate Code, UnIFORM L. Comm'n, http://www.nccusl.org/Act.aspx?title= probate \%20Code (last visited Oct. 28, 2011).

41. Unif. Computer Information Transactions Act (2001), available at http://www.law. upenn.edu/bll/archives/ulc/ucita/ucita200.htm.

42. See Acts: Computer Information Transaction Act, Unif. Law Comm'n, http://www.nccusl. org/Act.aspx?title=computer\%20Information \%20Transactions\%20Act (last visited Oct. 28, 2011).

43. Iowa Code § 554D.125 (2010); N.C. Gen Stat. § 66-329 (2010); Vt. Stat. Ann. tit. 9, $\S 2463 \mathrm{a}$ (2010); W. VA. CODE $§ 55-8-15$ (2010).

44. See generally, e.g., Ribstein \& Kobayashi, supra note 16; Janger, supra note 36. 
not seem to feel as compelled to maintain uniformity in any other area in a manner that even approaches remotely their rigid adherence to the uniformity of the Code.

The Article 9 revisions of the Code in 2001 are perhaps most instructive. ${ }^{45}$ The Drafting Committee completed the revisions in 1999 with the understanding that they would go into effect on July 1, 2001 for those states in which they had been enacted. ${ }^{46}$ Forty-eight out of fifty states enacted them by that date. ${ }^{47}$ By the end of that year, Article 9 was effective law in all fifty states, the District of Columbia, and the U.S. Virgin Islands. ${ }^{48}$ While it is true that no state has enacted the revisions to Article 2 proposed in $2003,{ }^{49}$ what is most interesting for our purposes is the manner in which in either case, uniformity is maintained. That is to say, revisions are proposed, and such revisions are either effectively rejected or accepted by the states as if they were a single constituent unit. The partial enactments that characterize nearly every single other uniform law proposal are absent.

\section{B. Nonuniformities and Heresies}

1. The PEB and the Protection of the Faith

As with any religion, the U.C.C. did not develop much of its rigid dogmatism until years after its initial promulgation. During the initial ten year period following Code promulgation, from 1952 to 1962, state enactments proceeded in a generally uniform fashion. ${ }^{50}$ However, this was also a period of frequent and fitful Code revision, enactment, and moderate individual state-by-state nonuniform adjustment, ${ }^{51}$ discussed in more detail below. ${ }^{52}$ For now, it suffices to note that states were behaving as rational actors in their adoptions, and in a manner generally consistent with the way in which they respond to other proposals emanating from the uniform laws processes.

45. The swiftness with which the Article 9 revisions took place also cast significant doubt on any position that American adherence to the Code is due to some innate feature of legal conservatism, where the United States' reluctance to reach any sort of global convergence on matters relating to security is simply due to the fact that the legal community has grown used to one system, and does not wish to learn anything new and is therefore institutionally resistant to any change that might be imposed on it. Suffice it to say that given the nature of the rewriting, many a commercial lawyer needed to learn a few new things upon the enactment of Revised Article 9. 46. WARREN \& WALT, supra note 29 , at 11.

47. Id.

48. Charles W. Mooney, Jr., Commercial Calamities: The Consumer Compromise in Revised U.C.C. Article 9: The Shame of it All, 68 Oн. Sт. L.J. 215, 216 (2007).

49. See infra Part (II)(B)(3).

50. E. Allan Farnsworth, Contracts $\S 1.9$, at 31 (4th ed. 2004).

51. Id.

52. See Section II(B)(3) infra. 
\begin{tabular}{lllll}
\hline |ljciprod01 $\backslash$ productn $\backslash \mathrm{D} \backslash \mathrm{DPB} \backslash 10-2 \backslash \mathrm{DPB} 203 . t \mathrm{txt}$ & unknown & Seq: 13 & 26-JAN-12 & 9:49 \\
\hline
\end{tabular}

Much has changed since that early period. The sponsoring organizations have proven themselves quite effective in limiting nonuniform enactments to the Code. This was achieved through the creation of the Permanent Editorial Board (PEB) in 1961, whose primary tasks were to preserve the sanctity of the urtext by "discouraging" nonuniform amendments and recommending changes as necessary. ${ }^{53}$ Protection of the Word thus became paramount virtue, through assigning the PEB two functions. The first of these was similar to the function of office of the Inquisition within the Vatican (since renamed the Congregation for the Doctrine of the Faith); namely, to "discourage" nonuniform amendments, or, as the Vatican would have it, to "spread sound doctrine and defend those points of Christian tradition which seem in danger because of new and unacceptable doctrines." ${ }_{54}$ The second function was to recommend changes to the ALI and ULC priesthood, presumably (given the first function) so as to enable, among other things, the maintaining of strict uniformity and the elimination of heresies by keeping the Code current and to the satisfaction of all. ${ }^{55}$

The institutionalization of Church dogma, and the consequent denial of legitimacy to any deviation as heresy, was thus subsequent to the initial creation of the Word, as it is within any religion. A prophet descends and with him comes the sacred Revelation. Yet disputes arise as to what that Revelation is, what it means, and divergent understandings begin to abound. In early Islamic history, for example, disputes arise as to the proper sources of law. One faction, the Mu'tazila, demand a prominent place for reason while others, led by the early jurist Shafi'i, emphasize the role of prophetic statements and utterances. Precisely what those utterances are become the subject of debate within the scholarly community as well, given the obvious temptation to fabricate to advance a material position. Nonuniformities, that is to say, proliferated as to the proper foundational material that may be deemed sacred and foundational. Eventually, within Sunni Islam, the matter is institutionalized into the four accepted schools of jurisprudence, what the Prophet said is canonized into sets of sacred

53. Current Projects: Permanent Editorial Board for the UCC, AM. L. Inst., http://www.ali.org/ index.cfm?fuseaction=projects.proj_ip\&projectid $=4$ (last visited Oct. 28, 2011) [hereinafter About the PEB].

54. See Congregation for the Doctrine of the Faith, VATicAn, http://www.vatican.va/roman curia/congregations/cfaith/documents/rc_con_cfaith_pro_14071997_en.html (last visited Nov. 20, 2011).

55. See infra Part (II)(B)(3) (addressing the (false) notion that by changing the Code to keep it current, the drafters are not engaged in a religious exercise because religious doctrine never changes). 
text, and deviations dismissed as heresy or worse, apostasy. The Word (and the institutions charged with its protection) thus remain cohesive, and adherence to them becomes Divine Command, where it was not decades earlier. A similar tale might be told of the vigorous disagreements in the early Catholic Church and the eventual canonization of the books of the New Testament. So it was with the canonization of the urtext and the concomitant rise of the PEB to protect it.

Churches of this sort rarely need to exercise direct state control to exercise their power so long as the relevant community has accepted both the religion as reflecting Divine Command, as well as the role of the church in defining that Divine Command. Thus, the connection of the PEB to any actual elected sovereign is attenuated. It is a joint committee of the ALI and the ULC. The ALI is an entirely private organization whose purpose, according to its own website, is to "produc[e] scholarly work to clarify, modernize, and otherwise improve the law." 56 The ULC is composed of representatives of the states, the District of Columbia, Puerto Rico and the U.S. Virgin Islands. ${ }^{57}$ These sovereigns fund it, though obviously its rulings would not be binding on any one of them. ${ }^{58}$

Thus, the high priests of the PEB retain no legal power over the sovereign states. Nevertheless, they are tasked by the High Church of the Code, the ALI, and the ULC, to ensure uniformity and they have as a result of this power, along with the broad religious faith of the commercial community in the Code, managed to achieve remarkable cohesion over the sanctity of the Word. Thus, it is precisely the religious power of the PEB as Church that enables it to exercise its "discouragement" function so well. If, again, we were to assume that the uniformity in text was merely product of rational decision making on a state-by-state basis, then the PEB's powers would be dramatically circumscribed. It would offer its rationally derived opinion, and one would expect that often enough a sovereign vested with actual legislative power would ignore it, for its own rational, or at least self-interested, reasons. It is religion, fundamentalist faith in the PEB and the institutions that created it, that confer upon it a majesty that any group of academics would almost never otherwise have in the halls of a state legislature.

56. About ALI, Ам. L. INST., http://www.ali.org/index.cfm?fuseaction=about.overview (last visited Oct. 28, 2011).

57. About ULC, Unif. L. Commission, http://www.nccusl.org/Narrative.aspx?title=about $\%$ 20the \%20ULC (last visited Oct. 28, 2011).

58. Benfield \& GREENFIELD, supra note 13 , at 3. 


\begin{tabular}{lllll}
\hline |ljciprod01 $\backslash$ productn $\backslash \mathrm{D} \backslash \mathrm{DPB} \backslash 10-2 \backslash \mathrm{DPB} 203 . t \mathrm{txt}$ & unknown & Seq: 15 & 26-JAN-12 & 9:49 \\
\hline
\end{tabular}

This power alone can be grounds for concern. Professors Ribstein and Kobayashi have studied the matter of adherence to uniform laws in economic terms, and have concluded that, though states generally adopt more efficient proposals and not less efficient ones, still states at times adopt uniform law proposals at the insistence of the Code's constituent organizations even when the results do not seem to lead to efficient outcomes. ${ }^{59}$ Such examples would include situations where state experimentation might produce more possible beneficial solutions than any single rule maker could. ${ }^{60}$

Ribstein and Kobayashi focus on the enactment of an entire uniform proposal, pointing out that they are not dealing with nonuniformities within the enactment itself. ${ }^{61}$ However, the issues they raise are even more pertinent in the context of potential nonuniform enactments to the Code. In those contexts, it is quite possible that a state's consideration of nonuniform amendment is driven precisely by its own particular needs, and to fail to enact them out of misplaced deference to the PEB's command as High Church leads to less efficient and less beneficial results. The religious fervor attached to the Code's urtext as Holy Text and the rejection of nonuniformity as heresy despite potential advantages to an individualized approach is perhaps best provided by way of a recent, important, representative $^{62}$ example provided in the next section.

\section{Article 9 and the Name}

To offer background, the purpose of Article 9, or any analogous regime respecting security for debt, is to offer secured creditors a means to have what is owed to them repaid from particular, specified secured property before other creditors may satisfy the debts owed them from the assets of an insolvent debtor's estate generally. ${ }^{63}$ Thus, to take the most common example of a secured transaction, a bank which has previously given a properly secured mortgage to an insolvent homeowner has, in bankruptcy, priority as concerns sale of that

\footnotetext{
59. Ribstein \& Kobayashi, supra note 16, at 132.

60. Id. at $140-41$.

61. Id. at $156-57$.

62. See infra Part (II)(B)(2). My example, in the following subsection, respecting an issue of nonuniformity as concerns Article 9, might be deemed selective, in that deviations from text as they concern Article 9 seem to result in an even more vociferous response than deviations in Article 2. This may be true, though it would take more than a footnote to explore it. It suffices to say, however, that in both cases, even if the reaction differs as to extent, the discouragement function of the PEB is significant enough to limit significantly nonuniform enactment across the entire Code, as I describe below.

63. See James J. White \& Robert S. Summers, Uniform Commercial Code 1150-51 (Thomson Reuters, 6th ed. 2010) (describing process in the context of the Code).
} 
property against all other creditors of that same debtor who have no security in the property, for example, credit card companies. The socalled unsecured creditors must be satisfied with dividing whatever proceeds remain from the sale of the secured asset after the secured creditor has been paid and whatever other secured assets the creditor might have.

In order to work, the system requires a notice filing and some sort of public recording system so that existing and potential creditors are on constructive notice respecting existing security obligations over the debtor's property. ${ }^{64}$ Under the Code, the notice filing undertaken by a creditor is known a financing statement, with the process of completion of the filing known as "perfection" of the security interest. ${ }^{65}$

Section 9-503(a) of the Code provides rules respecting the type of identifying information that must appear on a creditor's financing statement respecting the name of a debtor before the property of that debtor can be secured. ${ }^{66}$ For an individual, subsection 4 indicates that the statement is "only" sufficient if it "provides the individual . . . name of the debtor."67 A problem potentially arises as to what precisely an "individual name" is. Suppose, to take an entirely hypothetical example, that the person's name on her driver's license appears as "Jessie Allen." Would a financing statement with the name "Jessie Allen" suffice? Should a creditor ask for a birth certificate to see if the original name might be "Jessica" rather than "Jessie" because the name appears as if it might be a diminutive? If so, should they also verify there have been no name changes made in court since then? How much of this is really necessary for a creditor to undertake before offering a loan? The urtext, by saying nothing more than "individual name," is plainly ambiguous on the point and therefore patently unhelpful. To deal with this problem, several states adopted additional language creating a "safe harbor" indicating that the financing statement is per se effective respecting name if it includes the name of the individual as printed on her valid driver's license. ${ }^{68}$ One state went somewhat further, permitting a financing statement if it could be found via a future creditor's search of last names. ${ }^{69}$

\footnotetext{
64. Id.

65. Id.

66. U.C.C. § 9-503(a) (2011).

67. Id. $\S 9-503(\mathrm{a})(4)(\mathrm{A})$.

68. Compare Tenn. Code Ann. § 47-9-503(a)(4) (2010); Tex. Bus. \& Com. Code Ann. $\S$ 9.503(a)(4) (West 2002); Va. Code Ann. § 8.9A-503(a)(4) (2010) (granting a safe harbor) with U.C.C. $\$ 9-503(a)(4)(2011)$ (requiring individuals to include the "individual name" of the debtor, without defining how to determine it).

69. Neb. Rev. Stat. § 9-506(c) (2009) repealed by 2010 Neb. Laws 751.
} 
To the uninitiated, this seems rather harmless. I would describe it as salutary. At worst, the desire of a state to create a "safe harbor" for a financing statement by permitting reliance on a driver's license seems a rather pedestrian exercise of state sovereignty on a point of exceedingly minor concern. At best, this could be defended as an excellent example of federalism at work, an application of Brandeis' "state as laboratory" metaphor, ${ }^{70}$ or the type of circumstances where Professors Ribstein and Kobayashi might indicate state competition is preferable to uniformity. ${ }^{71}$ If greater clarity is achieved through the nonuniform enactment, we will have learned something. If not -if, as in Nebraska, there might be concern that merely the last name puts far too great a burden on those searching because of the large number of entries that might be found for common last names such as "Smith" or "Jones" - then this would be of some use to other states as well. In any event, state uniformity is hard to imagine even if no state undertook a uniform enactment. The urtext is so fundamentally ambiguous that there is little chance that there would be any uniformity in judicial application. Indeed, evidence suggests that courts have not been at all helpful in clarifying the meaning of the term "individual name" when applying § 9-503(a)(4). ${ }^{72}$ Where courts and the urtext have failed, the nonuniform enactment would, by contrast, provide precisely the type of clarity and simplicity, practicality and modernism, that the Code is supposed to provide, and, in this case, utterly fails to provide.

Instead of welcoming such limited and potentially helpful nonuniformity, however, something approaching apoplexy ensued in light of the rising heresy among the nonuniform states. This rather minor matter has been deemed, ominously, to mark the "end of uniformity." 73 With only nine years since its last effective enactment to Article 9, hardly much time for the Code in revised form to have percolated, this lack of uniformity is understood to have all but forced near immediate action through the enactment by the High Church of yet another set of amendments, precisely to rectify this problem and ensure uniformity to the Word. ${ }^{74}$ Ironically, for the priesthood of uni-

70. New State Ice Co. v. Liebmann, 285 U.S. 262, 311 (1932) (Brandeis, J. dissenting).

71. Ribstein \& Kobayashi, supra note 16, at 140.

72. Kevin V. Tu, The Rise of State-Specific Attempts to Decipher the Sufficiency-of-a-DebtorName Standard Under Revised Article 9 and the End of Uniformity in Secured Transactions, 59 U. Kan. L. Rev. 85, 96 (2010). See also Edwin E. Smith, A Summary of the 2010 Amendments to Article 9 of the Uniform Commercial Code, in Secured Transactions 2011: What Lawyers Need to Know About UCC Article 9, at 363, 369 (PLi Commercial Law \& Practice, Course Handbook Ser. No. 932, 2011), available at Westlaw 932 PLI/Comm 363 (describing this lack of uniformity as necessitating amendments to Revised Article 9).

73. Tu, supra note 72 , at 96.

74. Smith, supra note 72 , at $369-70$. 
formity, which forced this change because of deviations from the Code, the proposal they ended up with was itself not uniform. Instead it involved two alternatives, one of which made reliance on the driver's license all but mandatory, and the other which permitted it as a safe harbor, as three of the four original apostates from the urtext had suggested. ${ }^{75}$ There is an irony to this-nonuniformity to the urtext was deemed a reason to force early amendments, and yet, the urtext is in the proposed revisions itself nonuniform.

In other words, the difficulty with the nonuniform enactments, "discouraged" by the protectors of the doctrine, the PEB, was not their actual content, nor even the fact that they might result in a different outcome in different states, as the revisions contemplate something similar. It was, rather, that they were a heresy. They deviated in a fashion that the doctrine did not sanction, and that the high priests who control the Holy Text did not approve. It is hard to describe as rational a reaction to a deviation from Code as necessitating a set of amendments which themselves do not achieve uniformity. It is a far more satisfying analogy to imagine such reactions for what they were-precisely the rejection that the believer would have when Sacred Text is tampered with by those other than the institutions which have been given the authority to protect it and determine its true content. ${ }^{76}$

As for the fourth apostate, Nebraska, this amendment if enacted would make it something of an outlier, a continued dissenter from the demands of the Church in its insistence on reliance on a last name alone. But such apostasy does not often last long so long as a religious hierarchy is powerful enough, and this hierarchy is among the mightiest around. Before the proposed amendments were even complete, only one week and one year after they had even been made, Nebraska had repealed its nonuniform amendment. 77 Declaring the law "imme-

75. Id. at 375. The matter is more complicated than described in the text, though not in a manner relevant to this Article. For example, a debtor might not have a driver's license, or she might have two. The revisions address both possibilities. For the exact details, none of which are relevant to this Article, see $i d$.

76. In this way, the matter is somewhat different from a more philosophical quandary described in a scintillating piece by Perry Dane, of why a state which believed that its laws were in conformity with natural law would ever apply foreign law. Perry Dane, The Natural Law Challenge to Choice of Law in The Role of Ethics in InTERnational Law (Donald Earl Childress III ed., 2010), available at http://papers.ssrn.com/abstract_id=1710904. The issue in that example was an exclusivist certainty that the content of the laws in question were normatively superior to any other possible legal formulations. The issue here is more of an attachment not only to the law itself, in other words not merely to its values, but also to the institutions meant to protect ita religious-like faith, that is, in both the Word and the Church.

77. 2010 Neb. Laws 751. 
diately effective" because of an "emergency," the state brought itself safely back into the fold. ${ }^{78}$ Only Holy Roman Emperor Henry IV, barefoot at Canossa before Pope Gregory VII, sought repentance more urgently than this, for disobedience of far greater magnitude. ${ }^{79}$ If the amendments are enacted (a matter on which there is no guarantee, of course $),{ }^{80}$ then the Word will be restored among all states.

Admittedly, this is not the only example of nonuniform enactment. To take another example, some states in adopting the 2001 revisions to Article 1 have refused to include a revised definition of good faith that includes an objective component. ${ }^{81}$ One may safely say, however, that given the hyperbole that has arisen in the Article 9 "individual name" context, such nonuniformity is rare. It is frowned upon by the protectors of the doctrine, the PEB, whose function it is to "discourage" such appalling exercises of state sovereignty, ${ }^{82}$ which it has done quite effectively. The control of the High Church over ensuring uniformity to the urtext is so thorough that a justifiably highly respected member of prior Code Drafting Committees, Neil Cohen, felt understandably compelled, when explaining compromises made to interest groups in the drafting process, to state something which should have been obvious to anyone who had completed sixth grade civics-the urtext only becomes law when legislatures enact it. ${ }^{83}$

The irony is delicious. Had the Church been the elected federal government, another sovereign, it could never have exerted comparable levels of control. The anti-commandeering principles specifically limit the federal government's abilities to control state legislative enact-

78. Id.

79. Reportedly, Holy Roman Emperor Henry IV on his own and through bishops he had appointed had sought to force Pope Gregory VII to step down from his position. H.E.J. CowDrey, Pope Gregory VII 138 (1998). In response, Gregory VII excommunicated Henry IV and forbade anyone to serve him as king. Id. at 140-41. After it was clear that Henry IV would not succeed in his efforts, he was forced to seek repentance, walking barefoot in the snow to where the Pope was staying, in Canossa, and remain outside for three days begging for forgiveness before the interdiction was lifted. $I d$. at 155-57. As a condition of his absolution, Henry IV was required to "within the limit of time that the Lord Pope Gregory shall appoint, do . . . whatever is right according to his judgment." Id. at 157. See also Steven D. Smith, Discourse in the Dusk: The Twilight of Religious Freedom?, 122 Harv. L. Rev. 1869 (2009) (reviewing Kent Greenawalt, Religion and the Constitution - Volume 2: Establishment and Fairness (2008)).

80. See infra Part (II)(B) (respecting the increasing difficulty of amending the Code).

81. Benfield \& GreEnField, supra note 13 , at 171.

82. About the PEB, supra note 53.

83. Neil B. Cohen, Taking Democracy Seriously, 52 Hastings L.J. 667, 668 (2001) (addressing the question of Revised Article 2 and the ability of the PEB to force broad revisions to the Code onto the states). 
ment, even as to matters over which Congress has jurisdiction. ${ }^{84} \mathrm{Be}$ cause, as Cohen notes, the PEB is not a sovereign, because in fact it is an organization of high priests unconnected to any legal authority, the matter is different. They may not be able to legally "commandeer" anything, any more than the refusal of an orthodox Jewish husband to deliver a "get" to his wife prevents his wife from legally obtaining a civil divorce on whatever grounds are available in the relevant state's law. ${ }^{85}$ But to be an outcast, whether it be the state of Nebraska as concerns adherence to the Code, or the agunah as it concerns the dictates of orthodox Judaism, is deterrent enough within the community of the believers. ${ }^{86}$

\section{Revisions to the Word}

It might be appropriate to address here a preliminary objection, easily dispensed with, which is that a Holy Text does not change while the Code does, and with some frequency. Of this, two things might be said. First of all, the supposed distinction may be overstated. As was alluded to in the previous subsection, Holy Texts often change in early periods, and only after the passage of much time become largely unamendable. The books of the New Testament were canonized hundreds of years after the death of Jesus after much debate over their proper content. ${ }^{87}$ The main corpus of legal rules within Islamic Law, the compilation of utterances and actions of the Prophet Muhammad commonly referred to as the Sunna, were similarly canonized hundreds of years after the Prophet's death. ${ }^{88}$ A message is delivered,

84. See New York v. United States, 505 U.S. 144, 166 (1992) ("The allocation of power contained in the Commerce Clause . . . authorizes Congress to regulate interstate commerce directly; it does not authorize Congress to regulate state governments' regulation of interstate commerce.").

85. See Ran Hirschl, Constitutional Theocracy 201 (2010) (describing precisely such an issue as it arose in Canada in a case that reached the Canadian Supreme Court). Jewish law traditionally requires the delivery by the husband to the wife of what is known as the "get" in order for a woman to be legally divorced from her husband. Id. at 201. Absent this, the woman is known as an "agunah" and remains unable to marry within the faith community. Id. at 201. The issue was significant enough to result in the passage of two laws in New York that have the effect of requiring delivery of the get in order for a man to obtain a divorce and that permit consideration of whether or not the get has been granted when distributing property as between a divorcing couple. See Kent Greenawalt, Religious Law and Civil Law: Using Secular Law to Assure Observance of Practices with Religious Significance, 71 S. CAL. L. REv. 781, 823-35 (1998) (arguing that these laws are unconstitutional).

86. Greenawalt, supra note 85 , at 782. ("For some Jewish women, obtaining a get is vital to their prospects for a fulfilling life after civil divorce.").

87. Bruce M. Metzger, The Canon of the New Testament: Its Origin, Development, AND SignificANCE (1987).

88. Chibli Mallat, From Islamic to Middle Eastern Law a Restatement of the Field (Part I), 51 Ам. J. СомР. L. 699, 723-25 (2003) 


\begin{tabular}{lllll}
\hline I|jciprod01\productn $\backslash \mathrm{D} \backslash \mathrm{DPB} \backslash 10-2 \backslash \mathrm{DPB} 203 . t \mathrm{txt}$ & unknown & Seq: 21 & 26-JAN-12 & 9:49 \\
\hline
\end{tabular}

conflicting ideas about what it means begin to permeate, and at some point, a particular set of texts is formally sanctified as the Word; its alternatives thereby dismissed as heresy, or at least fabrication. ${ }^{89}$

Similarly, the UCC saw intense revision in its earliest period. In 1952, an Official Draft was promulgated and adopted in 1953 by Pennsylvania. ${ }^{90}$ Revisions were made, and a 1957 Official Draft promulgated, adopted by Massachusetts and Kentucky. ${ }^{91}$ A further set of amendments led to a 1958 Official Text, adopted by Connecticut and New Hampshire. ${ }^{92}$ Less than a decade after its enactment, the Uniform Commercial Code already had three versions, each of them in effect in different states. Adding further complication was the spread of heresies, through nonuniform enactment, by various states. ${ }^{93}$ It was precisely the spread of these heresies that led to a means of canonization through the establishment of the office of the Protection of the Faith, the PEB. Canonization soon followed. A single, uniform 1962 Official Version was then created, and enacted in all jurisdictions in its entirety except for Louisiana, which has not enacted Articles 2 or 2A. ${ }^{94}$ Alternate versions may not have been actively sought out and destroyed, as was the case with competing versions of the Qur'an in early Islamic history, ${ }^{95}$ such versions are nonetheless safely consigned to history's proverbial dustbin.

Importantly, as concerns Article 2, respecting the sale of goods, that all-important section with which first year law students are intimately familiar, there has yet to be another revision put into effect in the states. ${ }^{96}$ This is despite the fact that no less an authority than Nordstrom indicated in his Contracts hornbook in 1970, only eight years after the promulgation of the Official Text, that Article 2 required

89. In the case of the Prophetic Sunna, the quasi science of hadith reporting resulted in the broad dismissal of large amounts of the Sunna as being of weak provenance. Haider Ala Hamoudi, Muhammad's Social Justice or Muslim Cant?: Langdellianism and the Failures of Islamic Finance, 40 Cornell InT'L L.J. 89, 104-05 (2007). Similarly, canonization in the Christian tradition expelled competing versions of the Gospel from the New Testament. Metzger, supra note 87 .

90. Charles W. Mooney, Jr., Introduction to the Uniform Commercial Code Annual Survey: Some Observations on the Past, Present, and Future of the U.C.C., 41 Bus. Law. 1343, 1345 (1986).

91. Id.

92. Id.

93. FARNSWORTH, supra note $50, \S 1.9$, at 33 .

94. Benfield \& GREenfield, supra note 13 , at 5.

95. Bernard K. Freamon, Slavery, Freedom and the Doctrine of Consensus in Islamic Jurisprudence, 11 Harv. Hum. RTs. J. 1, 14 n.48 (1998).

96. BAIRD ET AL., supra note 5. 
amendment. ${ }^{97}$ Yet it is not so easy to revise a canonized Holy Text. There was an effort led by the PEB in 1987 to seek amendments to Article 2, and to work with the ALI on developing one through a Drafting Committee. ${ }^{98}$ It resulted in a completely revised version of Article 2 being approved by the ALI. ${ }^{99}$ However, it was never approved by the ULC, and thus it never reached the states. ${ }^{100}$ The ALI, PEB and ULC decided to try again, with something far less ambitious. ${ }^{101}$ If the urtext could not be rewritten entirely, they reasoned, perhaps it could be amended modestly. Yet even this proved to be impossible. The ALI and the ULC approved a series of amendments in 2003, and now, eight years after the fact, not a single state has enacted them. ${ }^{102}$

This should not be a surprise. A Church may readily be able to declare heretics and apostates on the basis of an existing Text, but once achieved, it is all the harder to credibly change the Text extensively. Similarly, it seems as if the PEB has been perhaps so good at the first part of its job, the Inquisition function of discouraging nonuniformity, that its ability to do the second part, recommend amendments, is severely compromised in effect. ${ }^{103}$ It has preserved the sanctity of the Word to such an extent that states find themselves remarkably reluctant to alter it even when the protectors of the dogma themselves recommend it. Indeed, while Article 2 is the starkest example of this, leading commercial lawyers indicate that the process of revision and enactment is becoming increasingly difficult over the Code as a whole. ${ }^{104}$ This is precisely as might be expected for a text, drafted and amended nearly annually during the first decade of its life, subsequently achieving canonical status. Opposition to Revised Article 2 has come from industry and consumers and is phrased in delightfully dystopian terms. To adopt Miller's phrasing, "to hear the criticism from those who purport to speak for both consumers and industry, one would think that Western civilization will end if amended Article 2 becomes law."105

97. Fred H. Miller, Uniform Commercial Code Article 2 on Sales of Goods and the Uniform Law Process: A True Story of Good v.?, 11 DuQ. Bus. L.J. 143 (2009).

98. Robert J. Nordstrom, Law of Sales §§ 2-3 (1970).

99. Miller, supra note 97 , at 155.

100. Id.

101. Id.

102. BAIRD ET AL., supra note 5.

103. About the PEB, supra note 53 (describing dual function of PEB).

104. BAIRD ET AL., supra note 5.

105. Miller, supra note 97 , at 165. 
This broad rejection from different interest groups, and the nature of the objection (presaging something disastrous) dispenses easily with any argument that the reason for the failure to amend has something to do with increased partisanship and interest group politics in our times. Nevertheless, even if partisanship were at play, such protestations would be odd, as they would seem to presuppose an era of initial Code drafting where partisanship and interest group politics were absent, or at least reduced. While this is precisely the manner in which the faithful often seem to describe their legends, rarely is the conception historically accurate. Whether Constitution or Qur'an, empirically disprovable mythologies develop respecting the political conditions of the origin of canonical texts that resemble Eden before the Fall-harmonious, generous and focused on the public interestas opposed to what are commonly depicted as our rancorous, partisan and self-serving times. ${ }^{106}$

This is no less so as concerns the origins of the Code. In fact, the Code's drafters included many political compromises into the Code in order to satisfy political interests whose support was needed for passage, as much scholarly work demonstrates. Robert Scott has shown the extent to which banking interests influenced the drafting of Article $9,{ }^{107}$ a point also emphasized in the work of Kathleen Patchel concerning Articles 3 and 4,108 and Edward Rubin regarding the revisions to those Articles. ${ }^{109}$ In a very thoughtful, well reasoned and provocative Article, Professor Janger effectively ties together some of these trends to identify where uniform law processes might fail because of "anticipated capture". This refers to the process by which the relevant drafting committee is so concerned about ultimate enactment that it

106. Just by way of example, what we know of early Islamic history following the Prophet's death is bloody, characterized by recourse to frequent internecine combat, including a large battle between the Prophet's son in law Ali b. Abi Talib and the Prophet's wife A'isha, occurring less than three decades after the death of the Prophet. Fatima Mernissi, The Veil and the Male Elite: A Feminist Interpretation of Women's Rights in Islam 49-50 (1992). Yet though this history is broadly, if reluctantly, acknowledged, one can hardly find a basic text on Islam that does not lionize the entire generation of the Prophet's Companions, without noting the obvious inconsistencies that arise by virtue of the internal conflicts. See, e.g., Annemarie Schimmel, Islam: An Introduction (1992).

107. Robert E. Scott, The Politics of Article 9, 80 VA. L. REv. 1783 (1994).

108. Kathleen Patchel, Interest Group Politics, Federalism, and the Uniform Laws Process: Some Lessons from the Uniform Commercial Code, 78 Minn L. Rev. 83, 98-102 (1993).

109. See Edward L. Rubin, Thinking like a Lawyer, Acting like a Lobbyist: Some Notes on Revising UCC Articles 3 and 4, 26 Loy. L.A. L. Rev. 743, 744-57 (1993), available at http:// digitalcommons.lmu.edu/llr/vol26/iss3/18. See also Homer Kripke, The Principles Underlying the Drafting of the Uniform Commercial Code, 1962 U. ILL. L.F. 321, 327 (1962) ("Not only were conservative tendencies present during the drafting; they were visible on the horizon at the legislative stage."). 
makes compromises to interest groups, not because of any actual pressure put upon it by such groups, but because it anticipates such pressure at the time of state-by-state enactment. ${ }^{110}$

This is to say nothing of the dramatic opposition to the Code even in the compromised, interest laden form in which it appeared. ${ }^{111}$ The stridency of some of the descriptions of the Code ("paternalist," "leftist," "social legislation"- a term which in today's parlance might be translated into "socialist"), resemble those which Fox News commentators might say of any number of Democratic proposals through history, from the New Deal through the Great Society to President Obama's health care overhaul. ${ }^{112}$ The Association of the Bar of the City of New York objected to the "new social tendencies" supposedly apparent in the Code, among them unconscionability. ${ }^{113}$ Moreover, as has been noted, partly at the urging of the City's Bar Association, the New York Law Review Commission seriously criticized the 1951 draft, leading to the failure of any state to enact it other than Pennsylvania until 1957.114 It also led to its substantial revision, recorded today in a leading hornbook in rather neutral terms, thereby suggesting New York was merely providing helpful suggestions on technical improvement. ${ }^{115}$ In historical context, the second effort was obviously an attempt to mollify the opposition to its supposed leftism by rendering it more favorable to business groups and, even more importantly, large banks. ${ }^{116}$

Thus, the National Association of Manufacturers may well have helped derail the first attempted revision of Article 2,117 but this hardly means that interest group influence had nothing to do with the manner in which the Code was first developed. It is difficult to read accounts of the initial period and come to the conclusion that interests were less divided than they are now. What was different was not the existence of partisanship and rancor, but the rather the fact that the Code had not yet been drafted and thus had not had the opportunity to reach the canonical status that it has now. It is much easier to defend that which has become sacred, to describe its amendment, even if

110. Janger, supra note 36 , at 578-80.

111. See, e.g., Frederick K. Beutel, The Proposed Uniform [?] Commercial Code Should not be Adopted, 61 Yale L.J. 334 (1952).

112. See Allen R. Kamp, Downtown Code: A History of the Uniform Commercial Code 19491954, 49 Buff. L. Rev. 359, 395 (2001).

113. Id. at 466-67.

114. Id. at 468; Patchel, supra note 108 , at 106.

115. FARnsworth, supra note 50, $\S 1.9$, at 41 (describing revisions in neutral terms).

116. Kamp, supra note 112, at 469-70 (describing historical processes); Patchel, supra note 108, at 106 (describing bank influence in forcing New York's revisions).

117. Miller, supra note 97, at 151. 
undertaken on moderate and sensible bases, as "the end of Western civilization," than it is to oppose the adoption of a new statute to deal with modes of commerce that are not governed by any similar holy text. Strong opposition and partisan objection will exist in any era. However, the sturdier the roots and the deeper the public attachment, the more likely that partisan efforts on the part of any particular interest group to oppose proposed revisions will be successful, because that group will be able to point to the sanctity of the Holy Text as a reason to retain it. I do not mean by this to suggest that there will be no future amendments, or to discount the substantial post-1962 amendments made to much of the Code, including the 2001 Article 9 revisions. The only point is that in fact, the dichotomy between the supposedly unamendable Holy Book and freely amendable Code is not as stark as it might at first blush appear to be.

The second, and perhaps more important, reason that equivalence of Word and Code is appropriate stems from the fact that the Code need not be equivalent to some form of inspired direct Revelation from God in order to be something akin to sacred text. That is to say, once one agrees to expand the definition of sacred text beyond merely the strict substance of Revelation (whether Bible, Qur'an, Torah or other Holy Book) to include the corpus of doctrinal rules, the objection that the Code is not sacred because it is freely amendable is effectively defeated. To go no further than the Catholic Church, it is church doctrine and not Holy Book that imposes the requirement of unmarried priests even as it was church doctrine that required the liturgy to be in Latin. ${ }^{118}$ One of these rules has been amended, the other has not. ${ }^{119}$ Yet each is, during the period of its effect, in its way, the Word. To deviate is to sin, and potentially to lose one's position within the Church, indeed even potentially to lose one's status as a member of the Church. ${ }^{120}$ The Church controls the substance of the Word, and the Congregation of the Doctrine of the Faith (the former office of Inquisition) protects the entire substance of that doctrine from deviancies and heresies-121 "discourages," as it were, nonuniform decisions with respect to it. That the doctrine has changed and is capa-

118. 1917 Code c. 928, translated in Edward N. Peters, The 1917 or Pio-Benedictine Code of CANON Law, 324-25 (2001); 1983 Code c.1037, available at http://www.vatican.va/ archive/ENG1104/_P3R.HTM.

119. Sacrosanctum Concilium [Constitution] Dec, 4, 1963, no. 36 \& (Vatican), available at http://www.vatican.va/archive/hist_councils/ii_vatican_council/documents/vat-ii_const_ 19631204_sacrosanctum-concilium_en.html.

120. 1917 Code c.1321-30 translated in Edward N. Peters, The 1917 or Pio-Benedictine Code of Canon Law, 445-48 (2001).

121. See About the PEB, supra note 53. 
\begin{tabular}{lllll}
\hline |ljciprod01 $\backslash$ productn $\backslash \mathrm{D} \backslash \mathrm{DPB} \backslash 10-2 \backslash \mathrm{DPB} 203 . t \mathrm{txt}$ & unknown & Seq: 26 & 26-JAN-12 & 9:49 \\
\hline
\end{tabular}

ble of changing in the future alters nothing with respect to these conclusions.

Shi'i Islam, for its part, much like the PEB, explicitly anticipates changes in religious doctrine, studiously recorded in the lengthy manuals of the senior jurists, by vesting in the senior jurists the ability to develop new rules, and to re-interpret old ones, without reference to prior determinations, a power known as ijtihad.122 This ability to amend does not divest the rules so derived of religious significancethe layperson remains bound by them as much as if they were not changed, it merely vests in the clergy the ability to make such changes. ${ }^{123}$ So it is with the Code, whose clergy happen to be law professors and judges rather than clerics and jurists. This is not meant to derogate from my earlier conclusion that change occurs more deliberately as matters become canonized-it is hard to imagine a Church engaged in Vatican II like reforms on an annual basis being able to survive-but it does mean that the mere fact of alteration does not render core doctrine reflected in sacred text as being somehow less than religious.

\section{Islamic Finance and the Code}

Analogies to other forms of modern commercial and legal practice as a form of religious doctrine are difficult to come by. In an intriguing article, Fletcher describes the United States Constitution, the French Code Civil, and the German Bürgerlischesgetzbuch (BGB) as being "nearly sacred books in Western law." 124 Fletcher has many interesting things to say about such matters, including the fact that the "nearly sacred" status afforded to the Code Civil in France and the BGB in Germany are not lessened by virtue of their frequent amendment, much as I have said is the case with the Code. ${ }^{125} \mathrm{He}$ also points out that the clarity and predictability of the Code Civil and BGB are largely a mirage, though his examples (tort, and general principles of contract) are less relevant in the core areas of commerce that are the subject of the UCC and, derivatively, this Article. ${ }^{126}$ Professor Hirschl likewise devotes an important section of his latest work to the manner in which constitutional law and religious law are far closer

122. Chibli Mallat, The Renewal of Islamic Law 31 (1993).

123. Haider Ala Hamoudi, You Say You Want a Revolution: Interpretive Communities and the Origins of Islamic Finance, 48 VA. J. INT'L L. 249, 268 (2008).

124. Fletcher, supra note 1.

125. Id. at 12 .

126. Id. at 11 . 
than is frequently assumed. ${ }^{127}$ Each has its sacred texts, its institutions designed to protect them, its competition as between interpretation and amendment, and its disputes over "originalist" and "purposivist" methodological approaches, to name some of the major similarities described.128 While the role of hierarchies in preserving the doctrine is intriguing, the areas of law specifically discussed by Hirschl are less relevant for the purposes of this Article. Finally, in discussing the role of faith in the context of understanding the constitution, Professor Levinson's excellent work on this subject and the rise of the "American civil religion" are deeply influential as a means to understand American attachment to its own unique forms of political governance. ${ }^{129}$

Thus, the comparison of constitutionalism to religious doctrine appears to be an attractive one to prominent scholars. Unfortunately, however, other scholars have not carried such ideas forward in the area of commerce. Yet as we have seen, it is difficult to justify or explain the near pathological aversion to nonuniform enactment, the rising inability to amend the Code, and the dramatic effectiveness of the PEB in its "discouraging" function despite the absence of recourse to legal sanction without some form of reverence to the urtext that resembles the adherence of the pious to Divine Commandment.

Islamic finance offers the most attractive analogy in its ability to develop a broadly convergent commercial practice on the basis of religious doctrine. The immensity of the task that was facing Islamic finance at its inception-creating a finance practice based on medieval texts with the slightest degree of relevance to the contemporary world-should not be gainsaid. Anyone seeking to make the effort in the previous century, when modern Islamic finance effectively began, ${ }^{130}$ was faced with a set of rules that can only be described as woefully anachronistic, if well developed for their time. ${ }^{131}$ A general theory of contract was absent from medieval Islamic commercial law. ${ }^{132}$ The medieval texts were rife with rules on conditions that might not be placed in contracts for sale. ${ }^{133}$ Even limitations respecting speculation were over matters that seemed either ridiculous or of-

127. HiRschl, supra note 85 , at 206-40.

128. Id. at 206.

129. LeVINSON, supra note 2.

130. The first Islamic banks were opened in the middle of the twentieth century. Hamoudi, supra note 89 , at 91 .

131. Haider Ala Hamoudi, The Muezzin's Call and the Dow Jones Bell: On the Necessity of Realism in the Study of Islamic Law, 56 Ам. J. CомP. L. 423, 436 (2008).

132. Id. at 438.

133. Id. at 439 . 
fensive (sale of the sperm of a stallion or purchase of the right to a runaway slave), hardly the rules from which a modern commercial practice could possibly be sensibly built. ${ }^{134}$ This, to be clear, is not an indictment of the rules in themselves, which as Professor Kuran notes no doubt worked well for their time, ${ }^{135}$ so much as a description of their general inapplicability in our own time.

By itself, this might not create significant barriers, as polities around the world have managed to adapt their legal systems creatively to meet current needs. ${ }^{136}$ Two additional problems existed as concerned Islamic finance, however. The first was that at the time when it first arose in force, in the latter half of the previous century, the commercial and financial legal regimes of the Muslim world were transplants from Western Europe. ${ }^{137}$ Modern Islamic rules needed to be developed against the backdrop of legal systems that paid no attention to them.

The second factor is even more relevant for our purposes, and what makes commitment to the practice of Islamic finance such a compelling analogy to American commercial commitment to the Code. As anyone even faintly familiar with geopolitical realities knows, there is no single Muslim regime, or any singular Muslim polity, in any but the most symbolic sense. Rather, the Muslim world has been divided into individual nation-states, and an increasing number of Muslims have begun to live outside of the Muslim world entirely through emigration. The level of coordination that would be necessary to achieve anything by way of uniform practice is daunting.

There are many reasons that Islamic finance managed to proliferate, and grow incredibly fast, notwithstanding these formidable obstacles, such that it is a practice with nearly $\$ 1$ trillion in assets at the present time. ${ }^{138}$ Most of them relate to a broad Muslim dissatisfaction with dominant global financial and economic paradigms, and a desire

134. Id. at 441 .

135. Timur Kuran, The Scale of Entrepreneurship in Middle Eastern History: Inhibitive Roles of Islamic Institutions, 19-21 (Econ. Research Initiatives at Duke, Working Paper No. 10, 2008), available at $\mathrm{http} / / /$ papers.ssrn.com/abstract_id=1265117.

136. The evolution of our own 1789 Constitution, whose drafters surely did not envision the state in which we currently reside, is only one example.

137. Hamoudi, supra note 89, at 91; Lama Abu-Odeh, The Politics of (Mis)Recognition: Islamic Law Pedagogy in American Academia, 52 Aм. J. Coмp. L. 789, 800-01 (2004).

138. Fouad Al-Salam, The Size and Scope of Islamic Finance: An Analysis, 25 InT'L J. Mgmt. 124, 125 (2008). This figure, from a March 2008 article, appears to be based on some level of reasonable analysis. Estimates vary from commentator to commentator, and in any event are hard to rely upon, as it is unimaginable that all financial institutions operating on a shari'a compliant basis, even if they could be located and counted, would be completely forthcoming on assets they currently have. 


\begin{tabular}{lllll}
\hline |jciprod01 $\backslash$ productn $\backslash \mathrm{D} \backslash \mathrm{DPB} \backslash 10-2 \backslash \mathrm{DPB} 203 . t \mathrm{txt}$ & unknown & Seq: 29 & 26-JAN-12 & 9:49 \\
\hline
\end{tabular}

for something more Islamically authentic, articulated as fairer, and more cognizant of social justice. ${ }^{139}$ For example, medieval prohibitions on the trades of certain commodities were transformed into the prohibition of money interest on a loan. ${ }^{140}$ The basis for this ban was that leading advocates of Islamic finance deemed it to be fairer than conventional finance because it prevented a rapacious capitalist class from effectively enslaving a working class by requiring laborers to take out debt for any projects they undertook, and to guarantee a return to the capitalists even if the debtors lost money on their ventures. ${ }^{141}$ Similarly, bans on speculation were understood to prevent one side of a transaction from being able to profit at the expense of the other on the basis of a change in external circumstances. ${ }^{142}$ In place of this world of heartlessness, with its winners and losers, its uncaring rich and its suffering poor, Islam was presumed to favor risk sharing, where profits and losses were won and lost by participants in a venture together, and no party could earn money while another lost it. ${ }^{143}$ All of this is recounted in other accounts of Islamic finance, and hardly needs more extensive treatment here. It suffices to say that for a variety of reasons, all of which are grounded in one way or another in the economic realities of our times, Islamic finance never succeeded along these lines, but instead expanded as successfully as it did by mimicking conventional financing techniques using alternative vehicles which achieve interest in all but name. ${ }^{144}$

The aspect of the story that goes unreported, however, is the extent to which the practice maintains its cohesiveness and general uniformity in the absence of anything like a governing Code. While there are respected organizations, among them the Accounting and Auditing Organization of Islamic Financial Institutions (AAOIFI), which issue guidelines respecting Islamic financial practices, ${ }^{145}$ they are often more honored in their breach than their observance. ${ }^{146}$ The actual

\footnotetext{
139. Hamoudi, supra note 130, at 433.

140. Id. at 447-49.

141. Id. at $452-53$.

142. Id. at 454 .

143. $I d$.

144. Hamoudi, supra note 87 , at 91 .

145. Holly E. Robbins, Note, Soul Searching and Profit Seeking: Reconciling the Competing Goals of Islamic Finance, 88 TEx. L. REv. 1125, 1133 (2010).

146. This is stated in characteristically elegant, yet diplomatic, terms, by a prominent law partner in the field, Philip Abbott of the Dubai office of Simmons and Simmons. After describing AAOIFI's role in setting standards for the field, he adds, however, that "market practice changes rapidly and therefore it is important to deploy market knowledge in the structuring stage of a transaction to save costs later on." Lucy Trevelyan, Weathering the Storm, INT'L B. Ass'N Global Insight, Apr. 2010, http://www.ibanet.org/Article/Detail.aspx?ArticleUid=03AE90318C66-48F3-906E-0B4BFADE5D37.
} 
certification of a particular transaction as suitably shari'a compliant comes not from adherence to any set of standards but rather the approval of a "shari'a review board" of the institution designing the transaction. ${ }^{147}$ To require each transaction to obtain the independent approval of a board of experts on the basis of difficult-to-ascertain criteria seems as if the practice would certainly devolve into entire incoherence as everyone claimed that anything imaginable was "Islamic," thereby making the term only one of marketing and not one signifying respect to any single set of rules. Perhaps counterintuitively, this has not proved to be the case.

This is not to say that the highly individualized and nonpublic method of ensuring shari'a compliance does not facilitate some form of rule-stretching and dubious transactional forms. While one could not know the extent of such practices given their nonpublic nature, one must assume that some level of considerable rule stretching does occur, and that this might even be the reason that a more formal set of rules for the practice universally applied has yet to be developed. Still, a certain practical coherence has taken hold that is undeniable. Particular bans appear at least formally absolute, most centrally, the taking of interest on debt. ${ }^{148}$ Those reformist Muslims who argue, plausibly enough, that the shari'a could be understood otherwise, ${ }^{149}$ are safely dismissed not quite as heretics, but as contemptible enough fellows-defeatist and apologists. ${ }^{150}$ Even practices that existed with some frequency in the classical world are dismissed as unacceptable heresies. The most obvious example is bay al-ina, where an object is sold for immediate cash, and then bought back by the original seller with a promise to pay a higher amount in the future. ${ }^{151}$ This is in Islamic finance universally dismissed as un-Islamic, an unacceptable circumventing of God's rule. Other innovations, such as the murabaha, not much different from bay al-ina except involving a third

147. $I d$.

148. See Council of Islamic Ideology, Consolidated Recommendations on the IsLAMic ECONOMIC System 7 (1983) (indicating the presence of "complete unanimity among all schools of thought in Islam that the term riba stands for interest in all its types and forms").

149. See Haider Ala Hamoudi, Jurisprudential Schizophrenia: On Form and Function in Islamic Finance, 7 CHI. J. INT'L L. 605, 611 (2007) (describing one approach to render the ban on interest inapplicable).

150. Muhammad Nejatullah Siddiqi, Banking without Interest 7 (1983) (describing the position permitting some forms of interest as "defeatist"); Muhammad Uzair, The Impact of Interest Free Banking, 3 J. Islamic Banking \& Fin. 39, 40 (1984) ("By this time, there is a complete consensus of all ... schools ... and among Islamic economists that interest in all forms, of all kinds, and for all purposes is completely prohibited in Islam. Gone are the days when people were apologetic about Islam and contended that interest for commercial and business purposes, as presently charged by banks, was not prohibited ....")

151. Hamoudi, supra note 131, at 443, 462. 


\begin{tabular}{lllll}
\hline |ljciprod01 $\backslash$ productn $\backslash \mathrm{D} \backslash \mathrm{DPB} \backslash 10-2 \backslash \mathrm{DPB} 203 . t x t$ & unknown & Seq: 31 & 26-JAN-12 & 9:49 \\
\hline
\end{tabular}

party, are by contrast embraced, or at least sanctioned, and form the backbone of the practice. ${ }^{152}$ Again, in the absence of any authority governing them, such matters of consensus have been achieved.

As new practices and new innovations develop, Islamic finance develops rules to govern them with similar uniformity. Once such rules promulgate, actors are hesitant to defy them, preferring to find a means of compliance rather than attempt to explain their heresies as somehow sound. An excellent example comes by way of the Islamic bond known as the sukuk. Told that the bondholder needed to "share" in profits and losses with the issuer as concerns whatever venture the issuer was engaged in, rather than receive a fixed interest based return, many financiers structured the transactions with a "target rate" based on a market measure such as the London Interbank Offering Rate (LIBOR). ${ }^{153}$ They then offered to the sukuk holder an interest free nonrecourse loan whenever the target rate was not met, and to the issuer a "reward" whenever the target rate was exceeded. The "reward" could be used to pay back the loan, thereby creating a conventional bond. ${ }^{154}$ It took a single, prominent Islamic finance expert to express disapproval of the practice, and in particular that portion related to the liberal resort to a non-recourse, interest free loan for the entire sukuk market to suffer dramatic reversals. ${ }^{155}$ The broad expectation is that as time progresses there will be a broad reformulation of the market to rid it of these sorts of innovations and heresies. ${ }^{156}$

What is striking is that precisely as with the Code's institutions, no authority exists with legal power to control or limit what might be called a transaction in "Islamic finance." Actors are perfectly free to ignore Islamic finance dictates and structure their transactions any way they wish, simply by convening a shari'a review board to their liking to bless it. Similarly, states are free to write their own independent and nonuniform code in derogation of the PEB, and an agunah is free to file for civil divorce and marry anyone she wishes. But when the matter is religious, and the penalty is heresy, blasphemy or exclusion from the community, as the case may be, the legal rules do not

152. Id. at 462 .

153. Haider Ala Hamoudi. Legal Lip Service, Forbes (Apr. 21, 2008, 6:00 PM), http:// www.forbes.com/2008/04/21/islamic-religious-banking-islamic-finance-cx_hh_islamicfinance08_ 0421spirit.html.

154. $I d$.

155. Id.; Michael J.T. McMillen, Asset Securitization Sukuk And Islamic Capital Markets: Structural Issues In These Formative Years, 25 Wisc. INT'L. L. J. 703, 743 (2008).

156. See McMillen, supra note 155 , at 743-44. 
offer the best guide as to compliance. Commercial religion, that is, proves remarkably effective as a form of constraint.

\section{The Problems of Commercial Religion}

\section{A. The Global Context}

Does this, however, create a problem? One immediate reply is that it could, in that it could restrain state competition in areas in which it would be more sensible to encourage it. We have seen such an example, or at least we potentially have, in the case of $\S 9-503.157$ Other dangers to uniformity as a more general matter, identified by Professors Ribstein and Kobayashi as they concern the enactment of uniform legislation generally (as opposed to enactment of uniform legislation with select nonuniform amendments) would include the difficulty of exit (as voters went to jurisdictions where they felt that the rules reflected their preferences better) and the ability to take into account local variation. ${ }^{158}$ One of the reasons, for example, that Texas may have been quick to enact $\S 9-503$ relates to the naming conventions of Hispanics, which result in names that might appear differently, or in different orders, in different official documents. ${ }^{159}$

At the same time, it is at least plausible to maintain that such examples are quite limited and are dwarfed by the advantages that uniformity more generally has provided. Perhaps, it might be argued, America's religious attachment to the Code manifests itself in some contexts in more strident a manner than is necessary, but the general effect of the uniformity can scarcely be doubted.

To see the more serious problem, one must look beyond American borders, and see the effects of America's adherence to its commercial religion on abilities to achieve some measure of uniformity across competing commercial law regimes.

Because of America's near religious faith in our own Holy Text and the High Church meant to preserve it, the United States has advanced something akin to broad scale proselytization to convert the world to its modalities of commercial regulation. This has, by and large, failed. I shall demonstrate this failure by reference to two of the Code's more prominent sections, both of which deal with areas of commerce in desperate need of uniformity, albeit in largely different manners. The balance of this Part shall deal with global divisions over security for a

157. U.C.C. § 9-503 (2001).

158. Ribstein \& Kobayashi, supra note 16, at 140-41.

159. U.C.C. § 9-503; Susan E. Collins \& Paul Hodnefeld, Current Revised Article 9 Search and Filing Issues, 42 TEx. J. Bus. L. 275, 284 (2007) (describing issues concerning Hispanic names). 


\begin{tabular}{lllll}
\hline |jciprod01 $\backslash$ productn $\backslash \mathrm{D} \backslash \mathrm{DPB} \backslash 10-2 \backslash \mathrm{DPB} 203 . t \mathrm{txt}$ & unknown & Seq: 33 & 26-JAN-12 & 9:49 \\
\hline
\end{tabular}

loan and America's implicit and unintended role in helping maintain the divisions; and the next Part shall deal with problems attaching to the sale of goods, notwithstanding the widely adopted Convention for the International Sale of Goods.

\section{B. The Contest Over Article 9}

Perhaps it behooves us, in addressing the deep structural problems attaching to global uniformity in secured transactions, to begin at the beginning; namely, a fuller description of the policies that underlie a secured credit regime.

The benefits of secured credit are obvious to anyone who has sought to take out a mortgage. Interest rates are considerably lower for a secured loan than they would be if there were no security regime for the obvious reason that debtor default does not pose as great a risk to the creditor when it is able to collect on proceeds arising from a sale of the secured property. There are two downsides, however, involving more vulnerable societal elements whom Professor Gilmore referred to, perhaps figuratively, as "widows and orphans." 160 The first relates to consumer protection, and ensuring that the individual consumer debtor is well aware of the consequences of permitting a lien to be placed on her personal property. Such protection, for example, would address concerns that an automobile purchaser may not understand the terms of repossession of her automobile. It could also deal with even more troubling practices involving purchase money security interests placed by stores on their credit cards with no more than language on the back of a charge slip. ${ }^{161}$ These very real concerns are, it can fairly be said, more acute in the domestic context than in the international: it is rare that consumers of this sort are part of a cross-border insolvency.

The more serious threat to Gilmore's figurative "widows and orphans" from an international perspective relates to the relationship of different classes of creditors to one another. To permit creditors to assert broadly security interests over any conceivable property of the debtor (bank accounts, revenue streams, tangible assets, etc.) often leaves nothing for junior or unsecured creditors. To the extent that these junior creditors are junk bondholders who were receiving relatively high interest payments corresponding to a risk premium, the matter might well be dismissed as a gamble that did not pay off. To

160. Grant Gilmore, The Good Faith Purchase Idea and the Uniform Commercial Code: Confessions of a Repentant Draftsman, 15 GA. L. Rev. 605, 620 (1981).

161. Janger, supra note 36 , at 612. 
the extent, however, that such creditors are involuntary creditors-an employer's pension fund, its employee compensation fund, its health plan, tort victims injured by the employer with unsatisfied claims against the employer-the matter becomes more troublesome.

The incentives of the firm are positively perverse under such a situation. To use a concrete example, if a company manufacturing oil drilling equipment is leveraged enough, so that it was (using entirely hypothetical numbers) a $\$ 700$ million company with $\$ 750$ million in liens filed against it, the wiser financial course would be to take excessive risks to produce its equipment cheaply so as to boost profits and increase its net worth. In the event that there is an occurrence (say the failure of the equipment leading to a catastrophic oil spill) that results in significant tort claims made against the company, the claims are hardly things to fear, as the company will not have to pay them. If the company petitions for bankruptcy, its secured creditors would liquidate it, acquire its assets and leave the tort claims unpaid. Neither they nor the company need be concerned. The trustee in bankruptcy is powerless to change the result - the trustee takes the place of a hypothetical lien creditor on the date of the bankruptcy petition, thereby rendering the trustee junior to secured claims already made. ${ }^{162}$ The incentive of the firm then is to satisfy its secured creditors at the expense of everyone else.

The problem is thus clear enough. Facilitate too much secured credit too easily, and tort victims go unpaid. Employees are dismissed from their company and unable to make claims on their pensions because of the employer's insolvency Facilitate too little, and the cost of credit rises unacceptably, consumers are unable to purchase homes or cars at reasonable prices, and economic slowdown is inevitable. The question is largely one of balance, as between the obvious social good provided by cheap commercial credit, and the equally obvious social good of protected consumers, employees, and tort victims.

Without going into legislative details, it is both fair and uncontroversial to say that Article 9 as originally drafted ran to the obvious advantage of large financial institutions at the expense of the more vulnerable. Gilmore himself expressed this concern respecting the original Article 9, of which he was a primary draftsman, shortly before his death. ${ }^{163}$ Musing on the wisdom of Judge Hand's earlier expressed skepticism respecting secured property, Gilmore asked, "why on earth

162. 11 U.S.C. $\$ 544$ (1994).

163. The two primary authors of original Article 9 were Gilmore and Alison Dunham. Janger, supra note 36 , at 571 . 


\begin{tabular}{lllll}
\hline |ljciprod01 $\backslash$ productn $\backslash \mathrm{D} \backslash \mathrm{DPB} \backslash 10-2 \backslash \mathrm{DPB} 203 . t x t$ & unknown & Seq: 35 & 26-JAN-12 & 9:49 \\
\hline
\end{tabular}

should the fruits of a known insolvent's labors feed the assignee while all the other creditors starve?"164

Given that even the draftsman of the original Code had discussed possible negative effects of the secured credit regime he had created, when the time came to enact a revised Article 9, a fair number of respectable authorities rose to offer greater protections to the unsecured creditors. Gail Hillebrand was in the forefront of efforts to provide consumer protection. ${ }^{165}$ Most prominently concerning the problem of unsecured creditors, no less an authority than Elizabeth Warren proposed an ingenious solution whereby a trustee in bankruptcy would be required to set aside twenty percent of a debtor's estate to satisfy the claims of unsecured creditors. ${ }^{166}$ Two equally impressive and authoritative scholars, Professors Bebchuck and Fried, adopting law and economics arguments, expressed similar concerns as those identified above. They proposed either a system of "partial priority," wherein a secured creditor would, under a variety of different formulations, be required to see part of its secured claim treated as on par with existing unsecured claims, or one granting involuntary creditors priority. ${ }^{167}$ Around the same time, Professor LoPucki famously argued that there was no reason that involuntary creditors should be junior in priority over secured creditors and many reasons to reverse that priority. ${ }^{168}$

To describe this latter set of proposals as having been rejected summarily by the committee charged to revise Article 9 is to understate the matter. They were not even considered, with a tone that at times bordered on the contemptuous. In a swipe clearly aimed at the substantial work of Bebchuck and Fried on the inefficiency of the existing regime, the co-reporters of the Drafting Committee, Charles Mooney and Steven Harris, described the "efficiency literature" as "interesting" but somehow not "cogent."169 Those concerned about the effects upon unsecured creditors were portrayed almost as hopeless bleeding hearts, dismissed derisively by Mooney and Harris as "Symps," or purveyors of "Sympathetic Legal Studies."170

\footnotetext{
164. Gilmore, supra note 160, at 627 (discussing Hand's decision in Rockmore v. Lehman). 165. Janger, supra note 36 , at 612.

166. Elizabeth Warren, Article 9 Set-Aside for Unsecured Creditors, 51 Consumer Fin. L. Q. REP. 323, 323 (1997).

167. Lucian Arye Bebchuk \& Jesse M. Fried, The Uneasy Case for the Priority of Secured Claims in Bankruptcy, 105 YALE L.J. 857, 905-12 (1996).

168. Lynn M. LoPucki, The Unsecured Creditor's Bargain, 80 VA. L. Rev. 1887, 1891 (1994).

169. Steven L. Harris \& Charles W. Mooney, Jr., A Property-Based Theory of Security Interests: Taking Debtors' Choices Seriously, 80 VA. L. Rev. 2021, 2023-24 (1994).

170. Id. at 2045.
} 
Concerns about consumer protection received a more sympathetic hearing from the Drafting Committee, though the ultimate result is no better than the original Article 9 and was very nearly much worse absent last minute maneuvering. ${ }^{171}$ The concerns about "anticipated capture" and the influence of banking interests of course can hardly be discounted in the reaching of this result. ${ }^{172}$ Nevertheless, whatever the reason, the revisions to Article 9, much like the original, discount and ignore the objections of scholars who suggested limitations on the free availability of secured credit.

\section{Transnational Objections to Secured Credit}

To be clear, the point of the previous section was not to reignite a debate that effectively ended with the adoption of Revised Article 9 in 2001. That issue has been decided in the United States, at least for now. It is enough to note that there are competing policies and interests involved, and that in credit-addled America, the notion of facilitating cheaper loans at the expense of almost any other interest imaginable comes not as an entire surprise.

The broader point is that once one leaves the United States, priorities are quite different, and those whom Mooney and Harris dismiss as "Symps" have a far greater hearing. This was clear in the UNCITRAL efforts to develop "legislative guidelines" for a more effective secured transactions law. ${ }^{173}$ Entering into what was known as Working Group VI, it was clear to participants that many nations were unconvinced that the social benefits that come with cheap credit were more substantial than those brought about by ensuring the fiscal health of pension funds, health care, worker's compensation and the like, even in insolvency proceedings. ${ }^{174}$

Evidence of this sentiment is evident in existing laws across developed and undeveloped jurisdictions in all parts of the globe. France, for example, subordinates secured claims to those of unpaid employees. ${ }^{175}$ Germany appears to have adopted provisions quite similar, if more limited, than those proposed by Warren, Bebchuck and Fried,

171. Janger, supra note 36 , at 613 .

172. $I d$.

173. UNCITRAL Legislative Guide on Secured Transactions, United NATions (2009), http:// www.uncitral.org/pdf/english/texts/security-lg/e/Terminology-and-Recs.18-1-10.pdf [hereinafter UNCITRAL Legislative Guide].

174. Roderick A. Macdonald, Three Metaphors of Norm Migration in International Context, 34 Brook. J. Int'L L. 603, 638-39 (2009).

175. James Leavy, France, in Cross-Border Security Over TAngibles 101, 108-09 (Harry C. Sigman \& Eva-Maria Kieninger eds. 2007). 
setting aside nine percent of claims for unsecured creditors. ${ }^{176}$ Italy not only provides a list of creditors who are prioritized over those of secured creditors, but has expanded the list in 2006. ${ }^{177}$ In my own extensive dealings with relevant committees within Iraq's Council of Representatives, the notion of security interests in personal property is often treated with noticeable hostility, with the notion of prioritization of the secured claim over involuntary, unsecured claims being among the premier objections. Following discussions over secured credit, a consumer protection law in which I played some role nearly included provisions limiting the applicability of secured credit, and this in a jurisdiction that does not yet recognize nonpossessory liens. The mere threat of more easily obtained secured credit was enough to induce consideration of consumer protection concerns, preemptively. In addition, most of East Asia tends to prioritize employee claims over those of secured creditors as well, though China has recently changed its law so as not to do so. ${ }^{178}$

There is thus considerable variation around the globe on these core policy questions, with comparatively few nations persuaded by America's extreme pro-creditor approach. There is also variation around the globe respecting archaic rules on secured transactions that do not appear to serve any contemporary policy interest. As noted, Iraq's current law generally requires liens either to be possessory, or some sort of document of title needs to be placed with the creditor, ${ }^{179}$ a largely pointless historical artifact that has its antecedents in Islamic Law as developed in the medieval era. ${ }^{180}$ This is not altogether different from many systems in predominantly Muslim countries. ${ }^{181}$ In other nations, similarly outdated rules exist. Among them is the requirement that security can only be taken out over a tangible object, as opposed to, for example, accounts receivable. 182 Such requirements, limiting both the types of property over which security could

176. Julia Rakob, Germany, in Cross-Border Security Over TAngibles 63, 70-71 (Harry Sigman \& Eva-Maria Kieninger eds. 2007).

177. Anna Veneziano, Italy, in Cross-Border Security Over Tangibles 159, 160-61 (Harry Sigman and \& Eva-Maria Kieninger eds. 2007).

178. Douglas W. Arner et al., Property Rights, Collateral, Creditor Rights, and Insolvency in East Asia, 42 Tex. Int'L L.J. 515, 557 (2007).

179. CoDE CIVIL arts. 1322-33 (1951) (Iraq), available at http://gjpi.org/wp-content/uploads/ 2009/01/civilcode928-end-x.pdf. See also Mark J. Sundahl, Iraq, Secured Transactions, and the Promise of Islamic Law, 40 VAnd. J. Transnat'L L. 1301, 1335 (2007).

180. Nicholas H.D. Foster, The Islamic Law of Real Security, 15 ArAB L.Q. 131, 136 (2000).

181. See, e.g., Michael J.T. McMillen, Islamic Shari'ah-Compliant Project Finance: Collateral Security and Financing Structure Case Studies, 24 Fordham InT'L L.J. 1184, 1221-22 (2001) (describing Saudi Arabia).

182. See, e.g., QAnuni Madani [Civil Code] 1928, art. 774 (Iran), available at http://www. unhcr.org/refworld/country,LEGAL,_LEGISLATION,IRN,,49997adb27,0.html. 
be had and requiring possession by the secured creditor, made sense in a world lacking sophisticated accounting or filing systems where creditors could be put on notice. Possession may well have been the only sensible way to notify the world that the property was secured by a third party. However, such rules are, to borrow the phrasing of Mooney and Harris, lacking in "cogent support" in any jurisdictions that are capable of maintaining adequate recording systems and in which decent accounting is possible. ${ }^{183}$ These draconian restrictions may well limit the ability of a debtor to tie up all of its assets in security, thereby leaving funds for unsecured and involuntary creditors. However, this is done at such a high price that it could fairly be argued that alternative and more limited means would be simultaneously more effective while still achieving the more substantial goal of a broad secured credit regime.

Adding to the difficulty is that unlike questions concerning the sale of goods, which may be handled by choice of law rules relatively well, secured credit requires something by way of uniformity in an increasingly globalized environment if it is to function. Professors Cohen and Smith do an admirable job describing why that is in the context of an excellent article describing some of the advantages and limitations of Article 9 internationally. ${ }^{184}$ To reduce the matter considerably, and to focus on only two more relevant issues, a mere choice of law in a credit agreement as between secured creditor and debtor could hardly serve to the end the matter, as future controversies will in many cases not be between those two parties, but rather between the secured creditor and unsecured or junior creditors, none of whom have signed the financing statement. ${ }^{185}$ Moreover, if the property is an asset which is not located in the United States, what American courts have to say about it will be of relatively little value. ${ }^{186}$

Thus, there is a significant divergence of secured transactions systems across the globe, and an urgent need for both harmonization and reform. In a world in which developed economies are consistently seeking sources of income in the developing world, and in which the developing world is seeking foreign investment, nothing could be more salutary than coming to agreement on a basic set of parameters. These would include discarding unnecessary artifacts that serve no purpose, and opening a frank and full discussion over the areas of

183. Harris \& Mooney, Jr., supra note 170, at 2023-24.

184. Neil B. Cohen \& Edwin E. Smith, International Secured Transactions and Revised UCC Article 9, 74 Chi.-Kent L. Rev. 1191, 1220-54 (1999).

185. Id. at $1236-37$.

186. Id. at 1222 . 
ideological division that do exist, among them the benefits of cheap credit on the one hand, and the rights of involuntary and unsecured creditors and broader notions of consumer protection on the other. If such an undertaking were attempted, its possibilities of success given the material advantages seem fairly significant.

I do not mean by this, I want to stress, that this would result in the creation of a global uniform code that would necessarily replace Article 9. I imagine that, to use the simplest example, European concerns over consumer protection are significantly strong, and American desires for cheap credit significantly deep, that a single uniform code to replace all domestic legislation would be extraordinarily difficult, and this as among jurisdictions with remarkably similar political systems and values. Yet some form of global convergence on some set of parameters might be possible. Treaties of significant scope could be contemplated, and a model law or set of laws, offering different possibilities and the advantages and disadvantages of each could be explored. Steps, that is, could be taken to accommodate different global systems in a manner that would help to ensure the freer flow of capital across jurisdictions.

\section{Article 9 and the World}

Unfortunately, instead of such a conversation and potential resulting convergence, what we witness is a transnational effort toward uniformity in the area of secured transactions of a different sort. It is best described as American commercial law advocates proselytizing for the effective adoption of the 2001 version of Article 9 worldwide with what can only be described as the zeal of the convert.

The advocacy for America's commercial religion is phrased in language that is both parochial and universalist, so extreme in its certainty of the rightness of America's path that proponents of other legislation in other transnational contexts would be embarrassed to use it. Drafters Mooney and Harris inform us that "many" believe that we have "the most successful commercial statute ever" in Article 9, the type of unfathomable hyperbole we only expect to hear about the United States as a nation, and even then only on Fox News. ${ }^{187}$ Our own casebooks, with which we train the next generation of American lawyers, find it untroubling to describe Article 9 in very similar terms. ${ }^{188}$ The view that this singular piece of legislation is the best law

187. Harris \& Mooney, Jr., supra note 169, at 2021 ("In embarking upon the revision of what many consider the most successful commercial statute ever[.]").

188. WARREN \& WALT, supra note 29, at 11 (endorsing "the widespread view that former Article 9 was the best commercial law statute ever written"). 
that has ever been written, not only in the area of secured transactions, but in all of commerce, is, as Professors Warren and Walt have noted, "widespread" (albeit only in American circles). ${ }^{189}$ Other than the Qur'an, and that in Islamic class as a child, I do not believe I have heard such a thing about any text.

When a community of believers, in this case much of the American commercial law elite, know the Truth (and it is hard to attach anything less than "Truth" to a suggestion that a piece of legislation is the "best ever"), there is nothing that can dislodge them of it. They will not seek grounds on which to develop in some limited space where accommodation is possible an alternative system of secured financing to that which is the "best ever"; they will merely try to convert others to the supposed "widespread view". Unsurprisingly as a result, there is nothing by way of acknowledgement that other approaches merit consideration, as they are merely "Symps," adherents to a different religion, one lacking "cogent support," no more worthy of consideration than it would be worthy for a Christian to consider adding several other gods to the Trinity.

Examples are many. In the context of Europe, the very notion that employees are to be protected in insolvency meets with scorn, without much by way of explanation. Sigman's work on "reforming" secured transactions around the globe is typical, a clear repudiation of priority to other classes of creditors except perhaps, and only perhaps, at the very margins. ${ }^{190}$ Those who have written chapters on his work on alternative systems in Europe have apparently joined the faith. They treat the notion of priority to involuntary creditors with some apology and embarrassment, dismissing the substantial reservation of nine percent of assets in Germany as being "very limited," 191 and protection of primarily involuntary creditors in Italy as "unsatisfactory." 192 The idea that these economically developed jurisdictions have reasons for such laws, which might be why (at least in the case of Italy) they have strengthened rather than weakened them in recent years, does not seem to come up.

Beyond Europe, the contempt is even more forthright. One of the major reforms that proselytizers deem necessary in Asia is granting further priority to creditors over unsecured employee claims for

189. Id.

190. Harry Sigman, Introduction, in Cross-Border Security Over Tangibles 1, 9-10 (Harry Sigman \& Eva-Maria Kieninger eds. 2007).

191. Rakob, supra note 176 , at 70.

192. Veneziano, supra note 177 , at 161. 
wages. ${ }^{193}$ No explanation is offered as to why-apparently it is self evident that a civilized nation would deem it less important for its workers to receive back pay (which can hardly be very much of a company's debt) as the company goes bankrupt rather than that Citibank maximizes its return. Even if our own academy had a thorough debate on precisely this subject at the time of the Article 9 revisions, we have had the benefit of the Church's rulings on the matter about a decade ago. In light of that, we no longer see enough merit in alternative systems even to discuss them, except as artifacts that need to be discarded. And why should we? Such protections are not part of Article 9, the Holy Text and the "best commercial law statute ever,"194 and hence cannot possibly be valid.

Lest one think this Holy Text, approved by our institutional Church, applies only to the chosen rich and developed, Revised Article 9 offers much more. Apparently it is "essential for the success of Iraq's future economic stability" to create a "progressive" secured transactions law, whose elements mirror Revised Article 9.195 Left unexplained is precisely why this is so in light of the fact that Iraq's revenue is likely to be oil driven at least for the near future and that oil companies seem content to invest significant sums elsewhere (including neighboring Saudi Arabia) ${ }^{196}$ without such a "progressive" law. For the even more desperately poor states of the world, secured transactions alleviate poverty. ${ }^{197}$ The Chinese factory worker who has lost his arm in a workplace accident due to inadequate safety measures and is now unable to recover from his employer because international banks have priority over him in insolvency proceedings might be excused for concluding otherwise. Whatever the state, and whatever the problem-economic development in post conflict societies to intractable poverty in desperately poor ones to enhancing wealth in already developed ones - the "best commercial law statute ever"198 can solve it, which is why the believers are puzzled as to why the entire world hasn't enacted it. Representatives of nations that might ask why it is that they must adopt the American model are accused incongruously of "autochthonous" behavior, lumped together with advocates of "Marxist-inspired" models of economic develop-

193. Arner et al., supra note 178 , at 557.

194. WARREN \& WALt, supra note 29, at 11.

195. Sundahl, supra note 179 , at 1303.

196. McMillen, supra note 181, at 1221-22.

197. Boris Kozolchyk, Secured Lending and its Poverty Reduction Effect, 42 Tex. InT'L L.J. 727 (2007).

198. WARREN \& WALt, supra note 29 , at 11. 
ment and "return to nature" types, incapable of comprehending the benefits of capitalism. ${ }^{199}$

Only to the skeptic is the accusation odd. The skeptic might wonder how the United States could accuse other states of clinging excessively to their own organic secured transactions models while at the same time demanding global compliance to the American model. Is not that very proselytization an even greater example of excessive enchantment with one's own law? "Autochthonous" behavior par excellence? Yet to the believer in a proselytizing religion, it is not so, for the Word is not in fact applicable only to the believer, but to all the peoples of the world who only need to understand its virtues to be saved, from whatever it is (poverty, resource curse, or anything else) that might afflict them-to live, if you will, the Good Life. Only a refusal to adopt the Word is parochial, a refusal to see a Universal Light apparent to the believer.

Yet despite the zeal, the missionaries of American commercial law, even with America's firm economic resolve behind them, have managed only the most limited of successes. It is true that the United States managed to use the UNCITRAL process to push through Working Group VI a Legislative Guide respecting secured transactions that replicated Revised Article 9 in large part, published by UNCITRAL in 2009 after many years of work. ${ }^{200}$ The Legislative Guide does offer helpful proposals, among them the removal of distinctions as between possessory and non-possessory liens and the permissibility of security to be obtained over intangible and even inchoate assets. ${ }^{201}$

Yet because this is a legislative guide and not a model law, it does not propose a law so much as provide recommendations on how to create one. As a result, core ideological disputes could safely be avoided, at least in part. For example, the guidelines do not prevent the law from creating preferences over secured creditors as to secured property. They merely require that the law "limit" those preferences, and that they be described "in a clear and specific way," a proposal I cannot imagine many would find objection with. ${ }^{202}$ Parameters that would be useful (who might have such priority, why might they have it, what are the limitations respecting it) are absent. In any event, in a world in which the best that UNCITRAL could do was a Legislative

199. Boris Kozolchyk, Modernization of Commercial Law: International Uniformity and Economic Development, 34 Brook. J. InT'l L. 709, 715 (2009).

200. Macdonald, supra note 174, at 640-41; UNCITRAL Legislative Guide, supra note 173. 201. UNCITRAL Legislative Guide, supra note 173, III 1(e), 16.

202. Id. If 83. The proposal does not provide, as Warren, Bebchuck and Fried had suggested in the American context, the possibility of a set aside for unsecured creditor. Id. II 84. 


\begin{tabular}{lllll}
\hline |jciprod01 $\backslash$ productn $\backslash \mathrm{D} \backslash \mathrm{DPB} \backslash 10-2 \backslash \mathrm{DPB} 203 . t \mathrm{txt}$ & unknown & Seq: 43 & 26-JAN-12 & 9:49 \\
\hline
\end{tabular}

Guide, not a model law, and even that after seven full years of effort, it is fair to describe harmonization as being some time away.

The United States cannot even manage to influence its own neighbors very much. Canada unsurprisingly has a secured transactions law, at least in the English speaking part of the country, which resembles Revised Article 9.203 Elsewhere, the story is hardly as encouraging. In a splendid article describing American pressure to impose Revised Article 9 globally, and corresponding Argentinean reticence that is similar in character to that shared by much of the globe, Professors Moglia Claps and McDonnell indicate that Argentina's legal community rejected efforts by its own banks to promote Revised Article 9.204 More broadly, the Organization of American States has created a model law for use in the Western hemisphere, which has similarly failed for the most part. Only a handful of small Central American states have adhered, as well as Peru, which found it unsatisfactory enough to make significant changes thereto. ${ }^{205}$ Even Mexico only partially adopted that model law, despite intense pressure put upon it by the United States. ${ }^{206}$

Elsewhere the story is similar. We have seen what American lawyers think of Asian models of secured transactions systems that favor employees in a venture over large financial institutions lending to it. ${ }^{207}$ The reaction of Asia itself has been decidedly cooler, even among proponents of secured transactions reform. While promoting a set of principles respecting secured transactions that resembles in some part Revised Article 9, the Asian Development Bank has at times shown impatience with American proselytization, arguing in a 2000 report that "there is no single model of a secured transactions legal regime" and that "this is not an area where one refers glibly to common law rules, general standards or global 'best international practices.'"208

203. Hale E. Sheppard, Overcoming Apathetic Internationalism to Generate Hemispheric Benefits: Analysis of and Arguments for Recent Secured Transactions Laws in Mexico, 10 J. TransNAT'L. L. \& POL'Y 133, 135-36 (2001).

204. Guillermo A. Moglia Claps \& Julian B. McDonnell, Secured Credit and Insolvency Law in Argentina and the U.S.: Gaining Insight from a Comparative Perspective, 30 GA. J. InT'L \& Comp. L. 393, 400 (2002).

205. Kozolchyk, supra note 199, at 725-30; Arnold S. Rosenberg et al., International Commercial Transactions, Franchising, and Distribution, 44 Int'l Law. 229 (2010).

206. Sandra M. Rocks \& Kate A. Sawyer, International Commercial Law: 2006 Developments, 62 Bus. Law. 1647, 1657 (2007); Moglia Claps \& McDonnell, supra note 204, at 398.

207. See Veneziano, supra note 177.

208. Arjun Goswami \& Hamid Sharif, Asian Dev. Bank, Law and Policy Reform at THE ADB Vol. II, 2000 Edition v (Dec. 2000), available at http://www.adb.org/documents/ others/law_adb/lpr_2000_2.asp?p=lawdevt\#contents. 
The reference to "common law rules" makes fairly clear whose efforts the ADB was castigating as "glib."

Europe has shown even less inclination to do very much about its secured transactions laws. Efforts to harmonize regimes within Europe fell apart in 2009, and the E.U. Member States have not signed the U.N. Convention on the Assignment of Receivables in Trade, which incorporates principles of Revised Article 9. ${ }^{209}$ To date, only four states have signed that convention. These are the United States, Madagascar, Liberia and Luxembourg, the final of these with an important choice of law reservation that has caused much European reticence. $^{210}$ Needless to say, something is amiss if America can do no better than enlist Madagascar and Liberia in its cause.

In a well-reasoned, well-considered and thoroughly commendable article, Professor Sundahl describes in some detail the rather stalled efforts at reaching some sort of resolution over secured transactions broadly, and then suggests that hope may come in a different and more gradualist approach, which he calls the "Cape Town approach." 211 Under this approach, adopted with respect to the Cape Town Convention on International Interests in Mobile Equipment, no effort is made to reach complete harmony over secured transactions, because frankly the matter is currently impossible. Instead, a focus is maintained over those areas in which there is the greatest need for low-cost financing, among them aircraft, oilrigs, and railway rolling stock. ${ }^{212}$ More importantly, rather than seek even agreement on these limited items, which was likewise impossible, at least in the short term, a base Convention was acceded to, following which the intention was to offer a series of protocols to which countries would separately accede. ${ }^{213}$ At the time of Sundahl's article, the first Protocol, concerning aircraft equipment had not only been finalized but also widely ratified by over fifty nations, from the United States to Afghanistan, ${ }^{214}$ making the matter rather significant given the near total lack of harmonization elsewhere.

209. Rosenberg et al., supra note 205, at 230.

210. Id.; Status 2001 - United Nations Convention on the Assignment of Receivables in International Trade, United NAtions Comm'N On InT'L Trade L., http://www.uncitral.org/uncitral/en/ uncitral_texts/payments/2001Convention_receivables_status.html (last visited Nov. 26, 2011) [hereinafter Status 2001].

211. Sundahl, supra note 26, at 345-54 (2006).

212. Id. at 349.

213. Id. at 353 .

214. Id. See also Int'L Inst. FOR Unification Private LAw, http://www.unidroit.org/english/ conventions/mobile-equipment/main.htm (last visited Oct. 30, 2011). 


\begin{tabular}{lllll}
\hline |ljciprod01 $\backslash$ productn $\backslash \mathrm{D} \backslash \mathrm{DPB} \backslash 10-2 \backslash \mathrm{DPB} 203 . t x t$ & unknown & Seq: 45 & 26-JAN-12 & 9:49 \\
\hline
\end{tabular}

Unfortunately, however, matters have not developed quite as harmoniously since. One other protocol has been adopted, concerning rolling railway stock, and it is essentially European rather than global, having been drafted in Luxembourg and adopted by (in addition to Luxembourg) the E.U., Gabon, Italy and Switzerland. ${ }^{215}$

I do not mean to suggest by this that Sundahl is not onto something in this admirable piece, for surely he is. Yet the limitations of the achievements in some ways point more clearly to the essential problems. Surely there are industries, among them those dealing in commercial aircraft, space assets and oilrigs, where the balance to be struck as between cheap credit and the protection of Gilmore's "widows and orphans" is somewhat different than that which might be applicable more generally. To take the easiest example, it is hard to believe that very many people think that broad consumer protection is necessary before a bank may obtain security in connection with a party's leveraged purchase of a Boeing 747. Any widow or orphan fortunate enough to be purchasing one needs no such protection. Moreover, the fact that airlines have very strong business related incentives to limit the crashing of their aircraft might also limit concerns relating to involuntary creditors such as tort victims. Finally, one cannot discount the significant expense of this sort of equipment as well as its obvious utility, together making cheap credit rather important in context.

The more interesting point, however, is that where some progress toward global convergence has been achieved, it has been where consensus along the lines of Revised Article 9 is most possible. That is to say, the conversation over harmonization seems as if it might bear fruit whenever it leads to conclusions that replicate those held by the priesthood of American commerce. It has failed, and failed miserably, in nearly every other instance.

This does not mean that Sundahl's "Cape Town approach" has run its course, for there are other industries, whether space assets or oil rigs, where similar consensus might be reached and a protocol adopted. It does mean that this neither presages broader convergence as to secured transactions legal regimes, nor the start of a genuine, frank, and open discussion and debate over the values that might un-

215. Luxembourg Protocol to the Convention on International Interests in Mobile Equipment on Matters Specific to Railway Rolling Stock, Int'L Inst. FOR Unification Private Law, http:// www.unidroit.org/english/implement/i-2007-railprotocol.pdf (last visited Oct. 30, 2011). It is fair to point out that the cross border traffic in railway stock is more significant in Europe than it is elsewhere, and certainly more important than it would be in North America. 
derlie them. This is at least partly because America adheres as tightly before Cape Town as after to its Code-inspired commercial religion.

\section{The Code And the CISG}

It could fairly be asked whether the adherence to Code as religious doctrine is truly a problem that infects commercial uniformity broadly, or whether there happens to be a single area, namely that of secured transactions, where the United States has been unusually stubborn. After all, as concerns the sale of goods, there exists a treaty to which the United States is signatory, the CISG, which could not be fairly described as merely replicating American notions of commercial order. ${ }^{216}$ Moreover, while the CISG is not universally adopted, or even nearly so, its adoption has been sufficiently broad and widespread that it is self-evidently an international legal obligation that reflects the interests of more than the United States. ${ }^{217}$

Yet the religious effect, caused by the hold of the Code, and in this case Article 2 thereof, on the American commercial imagination is quite real and limits the achievement of true harmonization of systems involving the sale of goods. This is because while the CISG may be formally ratified, all too often it ends up in judicial application being more mirage than expression of transnational harmony. This Part describes how and why this is.

216. See FARnsworth, supra note 50, 1.9 , at 34 (noting that CISG "displaces much of Article 2" of the Code).

217. See Kritzer, supra note 32 . While virtually all states in the world are involved in some cross border trade, less than half of the world has adopted the CISG. Exceptions are by no means marginal countries and include all of South Asia, Southeast Asia (except Singapore), a great deal of the Arab world and Africa. Id. Of the largest eight nations by population, only two (the United States and China) are signatories. Id. Three of the world's largest ten economies are likewise not parties. Id. This can be contrasted with the Convention for the International Enforcement of Arbitral Awards (the New York Convention) ratified by 145 nations, and the International Covenant of Civil and Political Rights, ratified by 167 nations. Ironically, the refusal of one state, the United Kingdom, to adopt the CISG may relate to its own excessive enchantment with its own domestic legal system. In explaining why the United Kingdom has yet to accede to the CISG, a leading commentator in an intriguing article suggests that the reasons may have to do with English "pride in its longstanding common law legal imperialism or in its long-treasured feeling of the superiority of English law to anything else that could even challenge it." A.F.M. Maniruzzaman, Formation of International Sales Contracts: A Comparative Perspective, 29 Int. Bus. Law. 483, 489 (2001). The notion is not altogether different from that which I have posited in the American context; namely, that combination of certainty, intransigence and unwillingness to compromise that motivates the believer in matters of core religious doctrine. 


\begin{tabular}{lllll}
\hline |ljciprod01 $\backslash$ productn $\backslash \mathrm{D} \backslash \mathrm{DPB} \backslash 10-2 \backslash \mathrm{DPB} 203 . t x t$ & unknown & Seq: 47 & 26-JAN-12 & 9:49 \\
\hline
\end{tabular}

\section{A. Understanding the CISG "Through a Domestic Lens"}

Given the extensive domestic adherence to the Code, described above, it should not be a surprise that the CISG has received anything but a welcome reception in U.S. courts. Rather, as many scholars have noted, ${ }^{218}$ and in Murray's memorable words in a laudable, brief comment on the subject ten years after the CISG came into force, courts have tended to "neglect" the CISG and view it "through the lens of domestic law."219

The point is important and requires elaboration. To any realist accustomed to giving praxis primacy over form, there is little that is uniform about the CISG given the manner in which it is treated in American courts. Uniformity in formal ratification may be interesting, but ultimately, if it does not lead to the attendant benefits of certainty and predictability across jurisdictions, it is of little use. If the uniformity is only in text but not in application in any given set of factual circumstances, then it is no uniformity at all, not to a commercial actor seeking to engage in cross border commerce and not to a commercial lawyer seeking to advise that actor.

Thus, developing nations may have broadly acceded to the New York Convention, as market signal if for no other reason, to signify that the state in question is "open for business" as it were. 220 But one need not travel far in the developing world to find myriad examples of domestic courts patently refusing to honor international arbitral awards on "public policy" exceptions, permitted by the New York Convention, that no court in the United States, for example, would take remotely seriously. ${ }^{221}$ The same may well be said of applications of the UNICTRAL Model Law when stays of domestic proceedings in deference of arbitration provisions are sought. 222

It would be convenient to dismiss this as merely byproduct of developing world judiciaries unable to grasp the complexities of international trade and finance-nothing more, that is, than an example of the difficulty in implementing the rule of law in the world's benighted regions. Such a conclusion would, however, be unjustified. The United States has shown no more practical uniformity in its interpretations of the CISG than the developing world has over the New York Convention. ${ }^{223}$ Thus, even with its independent judiciary, its embrace

218. See infra notes $262-65$ and accompanying text.

219. John Murray, The Neglect of CISG: A Workable Solution, 17 J. L. Cомм. 365, 371 (1998).

220. See supra note 203.

221. Mallat, supra note 34 .

222. Id.

223. See Murray, supra note 219, at 365-66. 
of the rule of law, its relative friendliness to the modalities of international commerce and finance, which after all have served it quite well, the United States, and more particularly its courts, have managed to interpret the CISG more often than not as little more than a somewhat imperfect reflection of their own domestic legislation. This is in marked contrast to the Code, whose urtext is interpreted, broadly speaking, quite uniformly, and where courts routinely refer to their sister jurisdictions in approaching the Holy Text.

A simple comparison of two Seventh Circuit decisions illustrates the distinction as between domestic uniformity in Code application and international heterogeneity in CISG interpretation quite well. First, to the Code: In the well known case of Northrop v. Litrionic Indus., the Seventh Circuit was faced with a central difficulty in the interpretation of $\S 2-207$, its famous "battle of the forms" section, dealing with what terms of two boilerplate forms should be included as part of the contract when terms on the forms conflict. ${ }^{224}$

Subsection two of that famous section discusses how to deal with "additional" terms but not different ones, leaving something of a gap that required filling. ${ }^{225}$ As the Northrop case notes, state courts in various jurisdictions have adopted three different approaches. ${ }^{226}$ The first, adopted by the majority of state jurisdictions, employs what is known as a "knockout" rule, wherein the conflicting terms are both removed from the contract. ${ }^{227}$ A second approach, adopted in some jurisdictions, is known as the "first shot" rule, and results in the removal of the offeree's conflicting term. ${ }^{228}$ The third option, favored by the Northrop court, as the most harmonious with the Code's language and its intent, is to treat the offeree's different terms as additional terms and then adopt the analysis of subsection two. ${ }^{229}$ Writing for the court, however, Judge Posner decided not to employ his own favored approach (after describing its advantages at some length), for two reasons. ${ }^{230}$ The first, and less interesting, reason was the court's determination that Illinois generally adopts the rule of a majority of jurisdictions, and the court was sitting in diversity and therefore was required to use the same approach.231 More importantly, Judge Posner pointed out that the Code strives to maintain interstate uniform-

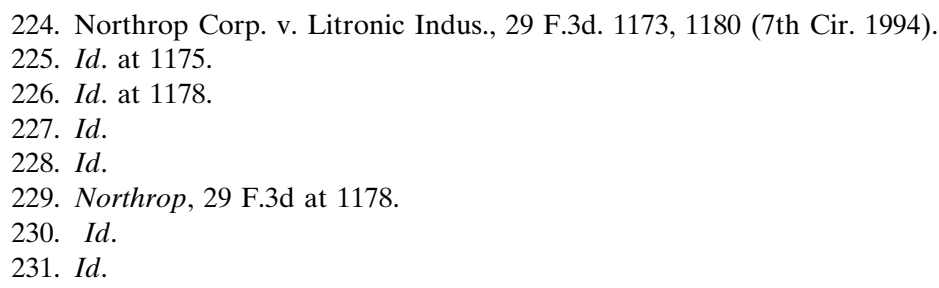




\begin{tabular}{lllll}
\hline |ljciprod01 $\backslash$ productn $\backslash \mathrm{D} \backslash \mathrm{DPB} \backslash 10-2 \backslash \mathrm{DPB} 203 . t x t$ & unknown & Seq: 49 & 26-JAN-12 & 9:49 \\
\hline
\end{tabular}

ity, and that therefore the court would presume that Illinois would adopt the majority rule if offered the choice. ${ }^{232}$ In other words, effectively left free to use any approach it wanted on a matter of Code interpretation where Illinois had not spoken, the court opted for uniformity across state jurisdictions, not because the rule was the correct one (in fact, the court described it as "imperfect") but rather because it would create uniformity, the proper approach to use in all circumstances except where the majority application happened to be "downright bad."233 The motivation for uniformity thus appears remarkably strong.

Of course, courts on occasion divide in their interpretations of the Code's sacred text. Clearly they have on the question discussed above, even if Illinois adheres to the majority view in the hopes of maximizing the possibility of uniformity. There are other issues respecting Article 2 where there are jurisdictional splits. The states have different views, for example on whether or not an implied warranty of merchantability may be extended by a buyer to a remote seller not in privity with the buyer. ${ }^{234}$ The applicability of the doctrine of estoppel to matters arising under the Code's Statute of Frauds is yet another example. ${ }^{235}$

Similarly, religious believers might split over the finer points of scripture. Sunni Muslim doctrine, as we have said, was traditionally determined by four Sunni schools, thereby implying some level of deviation, and Shi'i Muslim doctrine is determined by some limited and finite set of high clerics who do disagree with one another at times. ${ }^{236}$ To hold the doctrine sacred and to adopt it as a form of religious observance does not preclude the possibility of diverging interpretations of the same sacred doctrine. However, it does limit the levels of deviation, as believers and courts alike strive, when applying sacred text, to remain in some level of uniformity with others so as to ensure doctrinal integrity.

232. Id.

233. Id.

234. Compare Morrow v. New Moon Homes, Inc., 548 P.2d 279 (Alaska 1976) (holding that nonprivity manufacturer may be held liable for breach of implied warranty of merchantability) with Tex Enters., Inc. v. Brockway Standard, Inc., 66 P.3d 625 (Wash. 2003) (concluding the opposite).

235. Compare Lige Dickson Co. v. Union Oil Co. of Cal., 635 P.2d 103 (Wash. 1981) (holding estoppel inapplicable) with Decatur Coop. Assoc. v. Urban, 547 P.2d. 323 (Kan. 1976) (holding estoppel applicable).

236. An example exists in Shi'i Islam respecting the ritual cleanliness of people of other faiths. See Haider Ala Hamoudi, Between Realism and Resistance: Shi'i Islam and the Contemporary Liberal State, 11 J. Islamic L. \& Culture 107, 118 (2009). 
\begin{tabular}{lllll}
\hline |ljciprod01 $\backslash$ productn $\backslash \mathrm{D} \backslash \mathrm{DPB} \backslash 10-2 \backslash \mathrm{DPB} 203 . t x t$ & unknown & Seq: 50 & 26-JAN-12 & 9:49 \\
\hline
\end{tabular}

The same interest in uniformity does not apply as to international uniformity and the CISG, in the slightest. In the widely criticized Chicago Prime Packers decision, the Seventh Circuit, this time interpreting the CISG, shows no regard for uniformity at all.237 To be clear, and to reemphasize the point, the issue is not so much a court misunderstanding a foreign legal precept, thereby applying it incorrectly, or failing to take due account of context. This, as I have noted, is almost inevitable whenever a court is forced to deal with a law with which it is unfamiliar. Rather, as is demonstrated below, it is a matter of courts startlingly, and openly, refusing to even try to interpret the prevailing law of the land. The contempt this entails for an international treaty thereby surpasses normal expressions of parochialism.

In Prime Packers, a U.S. seller sued a Canadian buyer over spoiled ribs for which the buyer refused to pay, claiming that the ribs were not spoiled when delivered. ${ }^{238}$ While Article 36 of the CISG is reasonably clear that the seller is liable as to a nonconformity at the time of delivery, the issue in the case was instead over who bore the burden of proof to establish the alleged nonconformity, a matter on which the court determined the CISG was not clear. ${ }^{239}$

The Seventh Circuit could have adopted an approach similar to that which it employed in Northrop. It could have done this by accessing decisions of various nations to determine different approaches, easily done through the massive, impressive library of cases provided online by the Pace University School of Law CISG database, specifically cited in a 1998 Eleventh Circuit decision as being "a promising source." 240 Even if it considered itself too busy to refer to the Pace website, foreign law sources were available: the district court had referred to no less than seven foreign cases, ${ }^{241}$ leading some to conclude that perhaps the tide was turning on the use of foreign law in CISG cases. $^{242}$ Other resources might well be referred to as well in the in-

237. See Benfield, Jr. \& Greenfield, supra note 13, at 379; Shani Salama, Pragmatic Responses to Interpretive Impediments: Article 7 of the CISG, an Inter-American Application, $38 \mathrm{U}$. Miami Inter-Am. L. Rev. 225, 248 (2006).

238. Chi. Prime Packers, Inc. v. Northam Food Trading Co., 408 F.3d 894, 897 (7th Cir. 2005).

239. Id. at 898 .

240. MCC-Marble Ceramic Ctr., Inc. v. Ceramica Nuova D'Agostino, S.p.A., 144 F.3d 1384, 1390 n.14 (11th Cir. 1998).

241. Chi. Prime Packers, Inc. v. Northam Food Trading Co., 320 F. Supp. 2 d 702 (N.D. Ill. 2003).

242. Annabel Teiling, CISG: U.S. Court Relies on Foreign Case Law and the Internet, 2 UNIFORM L. Rev./Revue DE DROIT UNIFORME 431, 431-35 (2004), available at http://cisgw3.law. pace.edu/cisg/biblio/teiling.html; Harry M. Flechtner, The CISG in U.S. Courts: The Evolution (and Devolution) of the Methodology of Interpretation, in Quo VAdis CISG: Celebrating the 25th Anniversary of the United Nations Convention on Contracts for the Interna- 
terests of ensuring a pan-national approach, among them globally respected scholarly authorities. ${ }^{243}$ One would expect something like this type of effort. After all, the CISG has the promotion of uniformity as a central goal, precisely as the Code does, suggesting that the courts of other states, as well as globally respected authorities, must be deeply relevant to reaching the proper outcome. ${ }^{244}$

Instead, the court adopted an entirely different approach to "interpreting" the CISG, in derogation of the district court's attempt to find authority in foreign law. Essentially, it refused to apply it. First, the court referred sensibly enough to the "gap filler" provision of Article $7(2)$ of the CISG, which refers courts first to the "general principles" on which it is based (and which, it should be noted, follows immediately the requirement that courts interpret the CISG with a view to promoting uniformity). ${ }^{245}$ Those general principles, the court determined, could be found in the Code, America's sacred text. Moreover, the CISG, the court incredibly found, was the "international analogue" to the Code's Article 2.246 Many of its provisions were "the same or similar." 247 The Code, and American case law under it, could thus be used to interpret "analogous provisions" under the CISG, though the Code was not "per se applicable." 248 The remainder of the case applies the Code exclusively, as if it were the applicable law. ${ }^{249}$ Whatever progress the district court had made in its liberal use of foreign authority, the Seventh Circuit effectively reversed.

Moreover, in light of the lack of foreign authority, it is difficult to understand precisely what the court means when it declares that the Code's cases are not "per se applicable." 250 If the only sources of law the court used were the CISG's text and the Code, then this all but renders the Code per se applicable, except where the text of the CISG mandates a different result. That is, presumably, a "per se applicable"

tional SAle of Goods 91, 94 (Franco Ferrari ed. 2005); Francesco Mazzotta, Why do Some American Courts Fail To Get It Right?, 3 Loy. U. Chi. Int'L L. Rev. 85, 100 (2005).

243. The most prominent of these is the inestimable late Professor Honnold, whose work on the CISG is unparalleled. See generally John O. Honnold, Uniform Law for International Sales under the 1980 United Nations Convention (3d ed. 1999), available at http:// www.cisg.law.pace.edu/cisg/biblio/honnold.html.

244. United Nations Convention on Contracts for the International Sale of Goods art. 7(a), Apr. 11, 1980, 1489 U.N.T.S. 3, available at http://www.uncitral.org/pdf/english/texts/sales/cisg/ V1056997-CISG-e-book.pdf [hereinafter CISG].

245. Chi. Prime Packers, Inc. v. Northam Food Trading Co., 408 F.3d 894, 898 (7th Cir. 2005); CISG art. 2.

246. Prime Packers, 408 F.3d at 898.

247. $I d$.

248. $I d$.

249. See generally id. at 898-900.

250. Id. at 898 . 
rule would be one wherein, in the absence of a clear provision in the CISG, the rules of the Code would apply automatically. Under this approach, Articles 35 and 36 dealing with breach of warranty under the CISG would not provide a clear rule on burden of proof, in which case the Code would be deemed "per se applicable" and the matter interpreted according to the Code's warranty provisions. The court instead declared that there was no per se applicability but that in the case of ambiguity in a provision of the CISG, an analogous provision in the Code would be applied as the sole interpretive tool. ${ }^{251}$ In either case, the result appears to be precisely the same: the Code is to be applied, unless the CISG has a provision that clearly indicates otherwise.

To describe this as creating any sort of reasonable "uniformity" on a global scale is an impossible proposition to sustain. We may safely presume, after all, that the courts of other nations do not view the CISG as "international analogue" to the Code and are not likely therefore to reach similar conclusions except by mere happenstance. Certainly it seems unlikely that even if they knew the American interpretation they would deign to follow it given the parochialism of the reasoning.

Lest such an approach be dismissed as unique, the Court's theory is adopted from an earlier Second Circuit case decided in 1995, Delchiv. Rotorex. $^{252}$ The Second Circuit is more circumspect, but ultimately reaches the same effective conclusion-the Code applies when the text of the CISG is unclear. Specifically, the court reasons as follows:

Because there is virtually no caselaw under the Convention, we look to its language and to "the general principles" upon which it is based. The Convention directs that its interpretation be informed by its "international character and ... the need to promote uniformity in its application and the observance of good faith in international trade." Caselaw interpreting analogous provisions of Article 2 of the ... UCC, may also inform a court where the language of the relevant CISG provisions tracks that of the UCC. However, UCC caselaw "is not per se applicable." 253

In the first place, there is some irony in the final quoted line above because it references a U.S. Court of International Trade case to come to the conclusion that the Code is "not per se applicable" to cases decided under an international treaty designed to create international uniformity. It would be no less appropriate, after all, to cite a German

251. Prime Packers, 408 F.3d at 898.

252. Delchi Carrier SpA v. Rotorex Corp., 71 F.3d 1024, 1027-28 (2d Cir. 1995).

253. Id. (citations omitted). 
case thereafter which indicates that cases decided under the BGB may also be used even if they are not, similarly, "per se applicable."

More centrally, the entire passage is an incoherent and self-contradictory jumble. From the first sentence, we know to look to the language of the CISG and to "general principles," which are not entirely defined. ${ }^{254}$ The second sentence appears to provide some sort of guidance on general principles by suggesting that interpretation should be used "to promote uniformity in its application and the observance of good faith in international trade." 255 Yet in direct contradiction, the next sentence refers us to the Code, ${ }^{256}$ which clearly is not going to lead to any sort of reasonable international uniformity, for the simple reason that no court outside the United States would pay very much attention to it.

It is possible that the court meant only to apply the Code when international uniformity itself was difficult to ascertain. Yet this hardly seems to be the case, because the court does not seem concerned by international precedent. According to the court, there is "virtually no caselaw" under the CISG when in fact internationally by 1995, the date of the opinion, the number or recorded cases lay in the hundreds. ${ }^{257}$ Clearly the court meant that there was no case law in the United States; apparently it was not interested in looking elsewhere.

Thus, to paraphrase the Delchi court, to understand the language of the CISG, one refers to general principles. These general principles should preserve some level of international uniformity. However, to determine this international uniformity, neither international case law nor other international material will be accessed. The court may instead apply the Code, though it is not per se applicable, by the authority of the U.S. Court of International Trade. Where we end up after this confusion, it seems, is not altogether far from what Chicago Prime Packers implicitly derived as the relevant method of interpretationthe Code applies except when the language of the CISG clearly suggests otherwise.

In application, the Delchi court appears to have gone further still, effectively varying the words of the CISG to conform to American expectations. Article 74 of the CISG indicates quite plainly that damages that arise as a "possible consequence" of a party's breach are

257. CISG Database: Yearbook of CISG Cases: 1994-1993-1992-1991-1990, PACE L. SCH. INST. INT'L Coм. L., http://www.cisg.law.pace.edu/cisg/text/YB1994-1990.html (last visited Nov. 23, 2011). 


\begin{tabular}{lllll}
\hline |jciprod01 $\backslash$ productn $\backslash \mathrm{D} \backslash \mathrm{DPB} \backslash 10-2 \backslash \mathrm{DPB} 203 . t \mathrm{txt}$ & unknown & Seq: 54 & 26-JAN-12 & 9:49 \\
\hline
\end{tabular}

recoverable by the injured party. ${ }^{258}$ Yet the court suggests that the CISG adopts the "familiar principle of foreseeability" contained in the common law, and specifically the case of Hadley v. Baxendale, which limits damages to those incurred as a probable consequence of the breach. ${ }^{259}$ The court does not so much as remark on the important linguistic distinction, certain as it is that what the CISG has done is incorporate the wisdom of the common law.

Elsewhere, in deciding whether to include fixed and variable costs for lost profits calculations, the court blesses the adoption of what it calls the "standard formula employed by most American courts," for no reason other than the absence of a provision under the CISG. ${ }^{260}$ So much, then, for the "general principles" and international uniformity. By the time the opinion nears its end, given the relentless domestic focus, it seems as if the court has forgotten entirely that it is interpreting a treaty. ${ }^{261}$ It examines incidental and consequential damages under the provisions of the Code using its own Code case law without so much as reference to the CISG. ${ }^{262}$ The courts, it seems, cannot imagine using rules other than those set forth in the sacred text, and at times do not even pretend to try. These two Circuits are only examples. Others following them on their authority exist as well. ${ }^{263}$

\section{B. The Irrational and the Contemptuous}

It must be noted that the tendency to apply domestic law in interpreting an international treaty is not a problem of which the scholarly community is unaware. As early as 1989, Professor Honnold adopted a term to describe this disturbing tendency, the "homeward trend," that has been used subsequently. ${ }^{264}$ In 1999, a pessimistic commentator noted "the CISG does not bring uniformity to the law of interna-

258. CISG art. 74.

259. Delchi, 71 F.3d at 1029; see also Hadley v. Baxendale, (1854) 156 Eng. Rep. 145 (Ex.), available at http://www.law.berkeley.edu/faculty/rubinfeldd/LS145/hadley.html. Murray refers to this error as well. Murray, supra note 219, at 370.

260. Delchi, 71 F.3d at 1030.

261. See generally id. at 1030-31.

262. $I d$.

263. See, e.g., Raw Materials, Inc. v. Manfred Forberich GMBH \& Co., 53 Fed. R. Serv. 2d (Callaghan) 878 (N.D. Ill. 2004) (following Seventh Circuit); Genpharm, Inc. v. Pliva-Lachema, 361 F. Supp. $2 d 49$ (E.D.N.Y. 2005) (following Second Circuit).

264. John Honnold, Documentary History of the Uniform Law for International Sales 1 (1989). See also DiMatteo et al., The Interpretive Turn in International Sales Law: An Analysis of Fifteen Years of CISG Jurisprudence, 24 Nw. J. INT'L L. \& Bus. 299, 437-39 (2004) (describing the "persistence of homeward trend"). 
tional sales but instead fosters disharmony based on ignorance."265 Later reports are hardly more promising. ${ }^{266}$ In a particularly excellent article discussing this problem at length, Professor Flechtner describes the tendency of American courts to understand CISG doctrine through reference to the Code to be a form of "hallucination."267

As a result, the point here is not merely to repeat that which these excellent commentators have described, but to understand more thoroughly precisely why despite over a decade of criticism, American courts $^{268}$ have been unable to gravitate to anything approaching the uniformity in international sales that they have achieved quite well concerning domestic sales, and why their hostility to even trying seems so extreme. To understand this, a broader perspective is necessary, one that examines more generally America's largely stymied efforts to bring about commercial uniformity in any number of areas, and its concomitant attachment to the Code in nearly all instances. The matter, as we have seen, is based on a form of religious certainty, an attachment to a method of commercial dealing that is adhered to in a manner that transcends the rational, and a refusal to reconsider these general commercial norms even when they are rejected, or at least broadly challenged, by other important segments within the international community.

Stated differently, this is more than merely a problem of "homeward trend." It is a much broader hostility toward anything commercial that is foreign in origin. The severity and near irrationality of the

265. James E. Bailey, Facing the Truth: Seeing the Convention on Contracts for the International Sale of Goods as an Obstacle to a Uniform Law of International Sales, 32 Cornell InT'L L.J. 273, 281 (1999).

266. DiMatteo, supra note 264, at 437-39; Mazzotta, supra note 242, at 89-99 (2005); Salama, supra note 237, at 226.

267. Flechtner, supra note 242 , at 92 . Flechtner does point out that there are exceptions to the broader trend I have identified above, though ironically, the cases he cites as offering the most promising methodology are the Chicago Prime Packers case as decided in the district court (the Seventh Circuit decision not having been issued at time of publication) and a separate case in which the CISG was held not to apply. See Flechtner, supra 242, at 94, 97-98 (discussing the case of Amco Ukrservice v. Am. Meter Co., 312 F. Supp. 2d 681 (E.D. Pa. 2004)).

268. Admittedly, this is not an issue that is limited entirely to American courts, as other courts are likewise susceptible to the "homeward trend." See, e.g., DiMatteo et al., supra note 264, at 303-04 (describing an Italian case); Flechtner, supra note 242 (describing Belgian case where, ironically, rules of decision appear to arise neither in Belgium nor the CISG but rather from common civilian provisions respecting hardship). To this, two things may be said. First of all, it is not apparent that the problem is quite as serious elsewhere; one commentator describes Belgian and Italian courts generally as being particularly promising in their willingness to achieve international uniformity under the CISG, for example. See Mazzotta, supra note 242, at 90-91. Secondly, I do not discount the possibility of a quasi form of religious adherence on the part of civilian countries to their own civil codes, a matter which Fletcher has addressed at length in the context of France and Germany. Fletcher, supra note 1, at 11-18. 
unsympathetic reception of the CISG appears even when its interpretation in contradistinction to that of the Code turns out not to be at issue. The most memorable example comes in a case decided in the Southern District of New York, Filanto v. Chilewich. ${ }^{269}$ The issue in the case was whether or not the parties had agreed to arbitrate disputes between them, under factual circumstances that involved a dizzying array of competing forms, correspondence, and written and oral exchanges. Ultimately, the prevailing legal issues were relatively easy to resolve, because the court determined that one party had agreed to another's precise form, which included an arbitration clause. ${ }^{270}$ What was more striking, however, was the disdain for the CISG and the irrational attachment to the Code, under circumstances such attachment seemed, to say the least, dramatically misplaced.

There are some things that might be said in defense of the opinion and its treatment of the CISG. While like the Second Circuit in Delchi, the court felt it important to point out that there was virtually no case law on the CISG, at least it qualified its statement by making its reference exclusively to "U.S. case law." 271 This does not seem to have induced the court to look elsewhere for source material, though in the end it did not need to given the facts of the case.

Moreover, to its credit, and in sharp contrast with Delchi and Prime Packers, the court was also wise enough to indicate that the general principles of contract law did not include the Code. ${ }^{272}$ Were the same court to decide the matter today, it would almost surely decide, as per the Second Circuit's suggestion in Delchi, that "general principles," referring in this context to Article 7(2) of the CISG, were indeed embodied in the Code. ${ }^{273}$ Taken together with the dramatic reversal in respect for foreign law in connection with the handling of the Prime Packers case between the district court and the Seventh Circuit, ${ }^{274}$ this seems to indicate that judicial overreliance on the Code to understand the CISG is getting worse with time, rather than better. That is to say, even if the amount of case law in the U.S. increases in the future, this may increase American familiarity with the CISG at the expense of international uniformity as American courts stubbornly continue to separate themselves on the basis of their own unique domestic appli-

269. Filanto, S.p.A. v. Chilewich Int'l Corp., 789 F. Supp. 1229 (S.D.N.Y. 1992).

270. Id. at $1239-40$.

271. Id. at 1237.

272. Id. at 1237.

273. Delchi Carrier SpA v. Rotorex Corp., 71 F.3d 1024, 1027 (2d Cir. 1995).

274. See supra notes $240-49$ and accompanying text. 
\begin{tabular}{lllll}
\hline |ljciprod01 $\backslash$ productn $\backslash \mathrm{D} \backslash \mathrm{DPB} \backslash 10-2 \backslash \mathrm{DPB} 203 . t x t$ & unknown & Seq: 57 & 26-JAN-12 & 9:49 \\
\hline
\end{tabular}

cations not of the CISG, but of the Code-inspired American commercial religion.

Yet, whatever its merits, the Filanto decision could hardly be considered to be a particularly salutary exercise of CISG interpretation. In undertaking a preliminary analysis of the party's contentions, and noting the position of the plaintiff seller respecting the differing forms, material changes thereto, and $\S 2-207$, the court indicates as follows in a stunning passage:

Plaintiff Filanto's interpretation of the evidence is rather different. While Filanto apparently agrees that the March 13 Memorandum Agreement was indeed an offer, it characterizes its August 7 return of the signed Memorandum Agreement with the covering letter as a counteroffer. While defendant contends that under Uniform Commercial Code $\S 2-207$ this action would be viewed as an acceptance with a proposal for a material modification, the Uniform Commercial Code, as previously noted does not apply to this case, because the State Department undertook to fix something that was not broken by helping to create the Sale of Goods Convention which varies from the Uniform Commercial Code in many significant ways. ${ }^{275}$

Two observations may be made. The first is that the court seems not to have the slightest appreciation for the importance of facilitating some sort of international uniformity in commerce, dismissing any such effort as fixing "something that was not broken." 276 The Code, in other words, is sufficient, and whatever gains might exist in the harmonization of laws respecting international commerce are far outweighed by the sinful creation of a monstrous heresy, the CISG, that, horror of horrors, "varies from the . . . Code in many significant ways." 277

The second is that the context of the statement respecting unbroken Code is one that is very difficult to accord with reality, the product of religious faith rather than empirical observation. Under the facts as plaintiff presents them, the matter concerns a writing which contains a "different" term from that contained in the original agreement; namely, one pursuant to which a requirement for arbitration was eliminated. Under the supposedly "not broken" method of the Code, a court would first need to determine what rule in the relevant jurisdiction applied to "different" terms in conflicting forms-a "knockout rule," a "first shot rule," or a rule treating additional and different terms as synonymous and applying subsection two to both. ${ }^{278}$ If the

275. Filanto, 789 F. Supp. at 1238 (emphasis added).

276. $I d$.

277. $I d$.

278. See Northrop Corp. v. Litronic Indus., 29 F.3d. 1173, 1178 (7th Cir. 1994). 
first of these applies, the arbitration term is removed. If the second applies, the arbitration term is included. If the third, then the question turns on whether or not the arbitration term is material.

Hopefully, the third option does not turn out to be the one settled upon, or the work will just have begun. As Professor Farnsworth has correctly noted, vast sums have been spent deciding issues of materiality in many contexts, among them arbitration. ${ }^{279}$ The matter is in some jurisdictions held to be a question of fact for a jury to determine, and in other jurisdictions it is assumed to be material, at least in particular industries at particular times. ${ }^{280}$

Thus, if the Code's goals are simplicity, clarity, predictability, and uniformity, it is fair to describe $\$ 2-207$, and in particular in this very context, as deeply and fundamentally broken. There is nothing simple about the analysis, nothing predictable about the outcome, and nothing uniform given the vast multiplicity of rules applied in the various jurisdictions on just this matter. The reason to favor the Code has nothing to do with it not being broken; it has to do with adhering to it for its own sake, for the totemic value of its sacred words as opposed to those of the CISG.

After all, even the drafters of the Code offer no defense of $\S 2-207$ and in fact one is on record criticizing the professoriate precisely for holding the section in too much reverence. In a letter to the inestimable Professor Robert Summers, the equally inestimable Professor Grant Gilmore writes:

I do think that insufficient attention has been paid to the tangled drafting history of 2-207 . . . The point is that as late as the 1952 draft of the Code, 2-207 consisted only of what are now subsections (1) and (2). Subsection (3) was added in response to criticisms of the New York Law Revision Commission (which were probably based on suggestions by John Honnold, who acted as a consultant on Article 2 for the Commission). The 1952 version of 2-207 was bad enough (particularly in the $(2)(b)$ reference to "material alteration") but the addition of subsection (3), without the slightest explanation of how it was supposed to mesh with (1) and (2), turned the section into a complete disaster....

My principal quarrel with your discussion of 2-207 - and all the other discussions I have read - is that you treat the section much too respectfully - as if it had had sprung, all of a piece, like Minerva from the brow of Jove. The truth is that it was a miserable, bungled, patched-up job - both text and comment....

... .

279. FARNSWORTH, supra note 50, § 3.21, at 166 .

280. $I d$. 


\begin{tabular}{lllll}
\hline |ljciprod01 $\backslash$ productn $\backslash \mathrm{D} \backslash \mathrm{DPB} \backslash 10-2 \backslash \mathrm{DPB} 203 . t \mathrm{txt}$ & unknown & Seq: 59 & 26-JAN-12 & 9:49 \\
\hline
\end{tabular}

.... Perhaps there was something to be said for the common law rules of offer and acceptance. At all events: Down with 2-207. ${ }^{281}$

The irony should be obvious. One of the principal drafters of the Code is decrying religious-like reverence to the Code (hence the colorful mythological reference to Minerva springing from the brow of Jove), in particular as concerns $\S 2-207$, and even more specifically, as concerns the question of material alteration in subsection two. Gilmore describes it as "the greatest statutory mess of all time." 282 And about two decades later, a prestigious federal district court, presided over by one its sharpest legal minds over the past century, ${ }^{283}$ faced with a set of facts which demonstrate the extent of the incoherence over the section, and over that piece of the section specifically decried by Gilmore, ridicules the very existence of the CISG on the grounds that the Code is "not broken."284 The religion runs deep, so deep that even the drafters themselves cannot seem to dislodge it, any more than a believer can dispense readily with a verse of a Holy Book, even one whose content makes them uncomfortable.

To add to the irony, it might behoove us to investigate the outcome of the factual scenario posited by the Filanto court if the CISG were to apply, now that, as the court has indicated, the State Department had "fix[ed]" the unbroken section. ${ }^{285}$ The matter is simply, and uniformly, resolved under Article 19.286 The August 7 response letter contained a change respecting dispute resolution provisions to the earlier correspondence. ${ }^{287}$ Under subsection three of Article 19 of the CISG, such a change is material, and under subsections one and two, acceptances providing material changes to offers constitute counteroffers. ${ }^{288}$ The August 7 response letter would therefore plainly be a counteroffer under plaintiff's version of the facts.

Thus, what any rational analysis could conclude, and what Gilmore himself determined, was inexorably broken was, by the enactment of several lines of CISG text, fixed quite well. If, that is, the matter could be approached rationally.

\footnotetext{
281. Gilmore Letter, supra note 9, at 723-25 (emphasis added).

282. $I d$.

283. The Judge deciding the Filanto case was Chief Judge Charles Brieant, so respected that after his death, the courthouse in White Plains, New York was named after him. See The Hon. Charles L. Brieant Jr. Federal Building and Courthouse White Plains, New York, U.S. District Court S. District N.Y., http://www.nysd.uscourts.gov/site_whiteplains.php (last visited Nov. 6,

284. Filanto, 789 F. Supp. at 1137.

285. Id. at 1238 .

286. $I d$.

287. See id.

288. See CISG art. 19.
} 2011). 
\begin{tabular}{lllll}
\hline |jciprod01 $\backslash$ productn $\backslash \mathrm{D} \backslash \mathrm{DPB} \backslash 10-2 \backslash \mathrm{DPB} 203 . t \mathrm{txt}$ & unknown & Seq: 60 & 26-JAN-12 & 9:49 \\
\hline
\end{tabular}

To be clear, the issue is not any praise offered to $\S 2-207$ by the Filanto court. The court does not in fact laud the provision, and in any event other commentators and courts have in cases other than Filanto criticized $\S 2-207$. Rather, the problem demonstrated in Filanto that is deserving of attention is that when invited to consider an alternative model, one that plainly dealt with the problems of competing forms better, the Court not only could not bring itself to acknowledge that fact, but dismissed the entire CISG as unnecessary.

It is always easier to find fault with one's Holy Text than it is to adopt another. A religious Jew or Muslim , for example, might acknowledge discomfort with provisions of the Torah or Qur'an that seem to permit slavery or condemn homosexuality. It is quite another matter, however, to expect that person to admit the superiority of a competing Holy Book even if it were to address those issues in a fashion the believer found normatively appealing. This is because fundamentalist attachment to the Word is not merely about piecemeal adherence to appealing provisions, or those that suit from a normative or economic perspective. It is more entire than that; it is direct and full obedience to a comprehensive set of ideas, and an immediate and innate rejection of all that might conflict. So it was with Filanto. ${ }^{289}$

\section{Conclusion}

To grasp the nature of the dilemma facing global commercial practice because of America's quasi religious reverence to the Code as a form of sacred, canonical text, it is important to place the matter in its geographical and temporal context. The trends toward commercial uniformity in the two areas described in this Article in particular, areas in which there is growing need for some form of transnational resolution, are not encouraging. In the case of secured transactions, any hope of global convergence remains quite distant. There is only a legislative guide produced by UNCITRAL, ${ }^{290}$ whose influence is difficult to gauge, and a broad U.N. Convention which has only four signatories, the United States, Luxembourg, Liberia, and Madagascar. ${ }^{291}$ Europe has yet to harmonize its own systems internally, ${ }^{292}$ and virtually none of Latin America has adopted the Model Law promulgated by the Organization of American States, at least not without broad

289. Id.

290. See UNCITRAL Legislative Guide, supra note 173.

291. Status 2001, supra note 210.

292. See sources cited in supra note 206. 


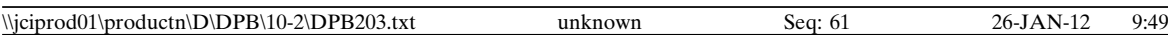

revisions thereto. ${ }^{293}$ The gradualist Cape Town approach has led to agreement on aircraft financing, which is helpful, but quite limited.294 If credit security is as fundamental to economic well being as its most zealous proselytizers seem to believe, then the time to engage seriously on a form of broader harmonization has been upon us for some time.

There can be no doubt that efforts have been undertaken, but one can ask whether or not they constitute engagement. Engagement requires exchange, and even those who should be the natural allies of the United States, such as the Asian Development Bank, which like all financial institutions stands much to gain from advancing secured transaction law, have recoiled from the United States efforts, ${ }^{295}$ which seem to be forever engaged in earnestly promoting its certainties that Article 9 is "the best commercial law statute ever" 296 and wondering aloud why the rest of the world has not simply adopted the American transplant.297 In any other context, such sentiments would be regarded as ridiculous. One can only imagine the reaction if President Bush, himself accused of trying to make Iraq in his own image, declared America's Constitution to be "the best ever" and if America's viceroy in Iraq, L. Paul Bremer, ${ }^{298}$ had subsequently held a conference entitled "Why Isn't Iraq Adopting the U.S. Constitution? Should It?" The Bush Administration was broadly indicted for far lesser sins. 299 Such proselytization, it seems, escapes public notice in matters of commerce.

And so we persist. Undeterred as proselytizers who cannot seem to convert very many to their one true faith, America's commercial law faithful remain steadfastly dedicated to the Code as godhead, necessarily "not broken" even under circumstances where all indications are to the contrary. Such an approach might be entirely legitimate for the missionary convinced that she is saving the souls of the damned, but it is not a basis upon which commercial uniformity can be achieved on a global scale.

293. Kozolchyk, supra note 199, at 725-30; Rosenberg, supra note 205, at 230; Rocks \& Sawyer, supra note 206, at 1657; Moglia Claps \& McDonnell, supra note 204, at 398.

294. See notes $210-14$ and accompanying text.

295. Goswami \& Sharif, supra note 208.

296. WARREN \& WALT, supra note 29, at 11; Harris \& Mooney, supra note 169, at 2021.

297. See supra Part III(D).

298. See Haider Ala Hamoudi, Money Laundering Amidst Mortars: Legislative Process and State Authority in Post-Invasion Iraq, 16 Transnat'L L. \& Contemp. Probs. 523, 526 (2007) (describing role of Bremer).

299. Id. at $528 \mathrm{n} .22$ (discussing putative legality of legislative orders made by American instituted authorities in Iraq). 
\begin{tabular}{lllll}
\hline |ljciprod01 $\backslash$ productn $\backslash \mathrm{D} \backslash \mathrm{DPB} \backslash 10-2 \backslash \mathrm{DPB} 203 . t x t$ & unknown & Seq: 62 & 26-JAN-12 & 9:49 \\
\hline
\end{tabular}

Limited, regional practices, such as Islamic finance, destined to remain largely insular to a devout community and hardly constituting a framework for a new global economic system (even if its proponents would like to believe otherwise) may comfortably remain religious in their orientation, certain of their rectitude and viewing compromise as a form of "defeatist" heresy. ${ }^{300}$ The United States can hardly afford the same result. Even as American commercial actors must suffer the peculiarities of nonuniform secured transaction laws around the globe, so must developing economies suffer a lack of investment for the same reason.

The resistance to a more syncretic approach, however, is deep and well nigh implacable. It runs not only among commercial lawyers and much of the professoriate, but as we have seen, to the judiciary as well. Our courts are hostile to the very notion of international commercial harmonization of any sort, even over matters that are less ideologically fraught than secured transactions. ${ }^{301}$ While the broad ideological harmony over the nature of sales as opposed to the benefits to be gained from secured transactions may explain why there is a CISG, it does not detract from the fact that the CISG is all too often less an actual binding treaty and more a text upon which the Code is imposed, to fill gaps, to interpret provisions, and even, in the Second Circuit, to qualify those provisions. Absent a provision of absolute clarity in the CISG (for example, its effective repeal of the Statute of Frauds), ${ }^{302}$ the approaches we have seen in the Second and Seventh Circuits do little more than offer lip service to international harmonization, and instead rely nearly exclusively on the Code and cases decided under it to derive their conclusions. ${ }^{303}$ In worse cases, the very notion of the CISG is derided, on the specious ground that somehow, $\S 2-207$ works fine, and somehow, that is the case even when the drafters themselves not only do not think so, indeed when the prophetdrafters criticize us for imagining that the clause arose as Minerva from Jove's brow. ${ }^{304}$ To defend the clause under such circumstances requires religious faith, as there is no rational basis upon which it can otherwise be defended.

"Homeward trends" undoubtedly exist with respect to any treaty. However if any other convention (say, the International Covenant on

\footnotetext{
300. See supra Part (II)(C).

301. See supra Part (IV).

302. CISG art. 11 (clearly repudiating requirements of a writing to evidence a contract).

303. See supra Part (IV)(B) (describing Delchi and Prime Packers cases).

304. Gilmore Letter, supra note 9 , at 723-25.
} 


\begin{tabular}{lllll}
\hline |jciprod01 $\backslash$ productn $\backslash \mathrm{D} \backslash \mathrm{DPB} \backslash 10-2 \backslash \mathrm{DPB} 203 . t \mathrm{txt}$ & unknown & Seq: 63 & 26-JAN-12 & 9:49 \\
\hline
\end{tabular}

Civil and Political Rights) ${ }^{305}$ had some of its key provisions ignored as broadly as the CISG, on the theory that the treaty was merely the "international analogue" 306 of something domestic (say, American anti-discrimination legislation), the outcry, it can be said, would be greater. Again, similar approaches seem to escape public notice when they deal with commercial matters.

Describing a comparable situation in the United Kingdom concerning its refusal to enact the CISG, a prominent commentator indicated as follows:

Although the English common law of contract, like any other branch of English law, was considered to be influential in many parts of the world, especially the commonwealth and common law jurisdictions, such complacency should no longer exist in light of the recent move towards the globalisation and liberalisation of international trade. The United Kingdom has not yet ratified the CISG, perhaps because of pride in its longstanding common law legal imperialism or in its long-treasured feeling of the superiority of English law to anything else that could even challenge it ....

With the anticipated acceleration of globalisation and liberalisation movements in the near future, there will be a greater demand for the global harmonization of commercial law. In such a situation, the insular attitude of the United Kingdom to the harmonization phenomenon is, in fact, regrettable. The time has come to wake up and face reality, and deal with it effectively.

The world has so far been deprived of the reputable talent of British judges and lawyers in the matter of interpretation of the CISG which could have influenced the harmonization process in judicial decisions in the same way as the common law has in many countries. ${ }^{307}$

Precisely the same may fairly be said, mutatis mutandis as concerns the United States, and with respect to a far greater scope of commercial activities. Our ability to influence the outcomes concerning both a secured transactions law, and a more truly uniform CISG are greater now than they are likely to be at any time in the foreseeable future. Yet the opportunity is squandered by our adherence to our commercial religion, and our concomitant refusal to countenance anything but a global Revised Article 9 in the one case, and the adoption of judicial reasoning that no court beyond the United States would find remotely appealing in the other. It would be unfortunate, indeed tragic, if the

305. International Covenant on Civil and Political Rights, adopted Dec. 16, 1966, S. Exec. Doc. E, 95-2 (19878), 999 U.N.T.S. 171 (entered into force Mar. 3, 1976); available at http:// www2.ohchr.org/english/law/ccpr.htm.

306. See Chi. Prime Packers, Inc. v. Northam Food Trading Co., 408 F.3d 894, 898 (7th Cir. 2005).

307. Maniruzzaman, supra note 217. 
364 DePaul Business \& Commercial Law Journal [Vol. 10:301

Code which served America so well in the latter half of the last century prevented its ability to develop a new Code, no less uniform in text and application, but of far broader scope. The challenges are great, but they can be surmounted. To turn the words of Filanto court around on their head, the system is quite broken. ${ }^{308}$ We need a new religion. 